\title{
New Light on Historical Specimens Reveals a New Species of Ladybird (Coleoptera: Coccinellidae): Morphological, Museomic, and Phylogenetic Analyses
}

\author{
Karen Salazar ${ }^{1,2, *(\mathbb{D})}$ and Romain Nattier ${ }^{1}$ \\ 1 Institut de Systématique, Evolution, Biodiversité (ISYEB), Muséum national d'Histoire naturelle, CNRS, \\ Sorbonne Université, EPHE, Université des Antilles, 57 rue Cuvier, CP 50, 75005 Paris, France; \\ nattier@mnhn.fr \\ 2 Grupo de Investigación Insectos de Colombia, Instituto de Ciencias Naturales, \\ Universidad Nacional de Colombia, Ciudad Universitaria, Bogotá 111321, Colombia \\ * Correspondence: karen.salazar@mnhn.fr
}

Received: 2 October 2020; Accepted: 27 October 2020; Published: 6 November 2020

Simple Summary: Biological collections are a valuable source of genetic information. Museomics in combination with morphological analysis is useful for systematic studies. Eriopis is a genus of ladybird beetles (Coccinellidae) that lives in South America. This study presents Eriopis patagonia, a new species of ladybird beetle discovered with two old specimens collected in Patagonia at least 100 years ago and deposited in a natural history collection. DNA was extracted from the specimens by a non-destructive method, allowing the specimens to be preserved again. The total gDNA was sequenced using Next-Generation Sequencing (NGS) technologies. The genetic information obtained allows us to reconstruct and describe its mitochondrial genome and examine its phylogenetic position.

\begin{abstract}
Natural history collections house an important source of genetic data from yet unexplored biological diversity. Molecular data from museum specimens remain underexploited, which is mainly due to the degradation of DNA from specimens over time. However, Next-Generation Sequencing (NGS) technology can now be used to sequence "old" specimens. Indeed, many of these specimens are unique samples of nomenclatural types and can be crucial for resolving systematic or biogeographic scientific questions. Two ladybird beetle specimens from Patagonia corresponding to a new species of the genus Eriopis Mulsant were found in the collections of the Muséum national d'Histoire naturelle (MNHN), Paris. Here, we describe Eriopis patagonia Salazar, sp. nov. Total DNA of one of the two specimens was sequenced by NGS using a paired-end Illumina approach. We reconstruct and characterize the mitochondrial genome of this species $(16,194 \mathrm{bp})$. Then, the protein-coding genes (PCGs) and ribosomal RNAs (rRNAs) were used to infer by maximum likelihood and Bayesian Inference the phylogenetic position of E. patagonia among 27 representatives of Coccinellidae. Phylogenetic analysis confirmed the position of Eriopis as sister group to Cycloneda Crotch. Hence, we highlight the high potential of sequencing technology for extracting molecular information from old specimens, which are used here for the systematic study of a genus, while demonstrating the importance of preserving biological collections.
\end{abstract}

Keywords: biological collections; Coleoptera; Illumina; mitogenome; molecular phylogeny; NGS; South America; taxonomy; type specimens

\section{Introduction}

Natural history collections (NHCs) are spatio-temporal testimonies of biological diversity and serve as an invaluable tool for documenting changes in biodiversity over time [1-3]. The acquisition 
of genetic data from NHC specimens is made difficult by processes such as DNA degradation, DNA fragmentation, and contamination. The degradation of a specimen's DNA over time begins postmortem and increases over time depending on storage conditions, resulting in DNA fragmentation and reducing the quality and quantity of usable DNA from older NHC specimens (reviewed in $[4,5]$ ). Next-Generation Sequencing (NGS) is a high-throughput data collection method that uses short read sequences as templates, thus making it possible to bypass the above-mentioned difficulties by sequencing the highly fragmented DNA of old specimens [6-8]. The use of NGS for low-coverage whole genome sequencing is called "Genome Skimming" $[9,10]$. This method has been successfully applied to obtain plastomes, mitogenomes, and repetitive nuclear loci from various plant (e.g., [11-13]) and animal groups (e.g., insects [14,15]; annelids [16]; crayfish [17]). Furthermore, non-destructive protocols allow the extraction of DNA from rare or unique samples and type specimens from NHCs. For arthropods, the most common protocol consists in placing the entire specimen in a lysis buffer to extract its DNA. This process causes no discernible external morphological damage and sample specimens can be stored again in NHCs [18-21].

Specimens kept in NHCs are often used in a traditional taxonomic context [5]. However, these specimens also contain genetic information waiting to be explored. For example, museomics has been used to resolve phylogenies (e.g., [22-24]), for accurate species designation using DNA from type specimens $[25,26]$, to reveal cryptic species [27], to assess the phylogenetic relationship of extinct lineages (e.g., [28,29]), and to investigate genetic changes in populations over time [4]. Furthermore, molecular analysis of old museum specimens can also accelerate the process of species discovery [30].

Very few studies have recovered genetic information from old beetle (Coleoptera) specimens deposited at NHCs. Maddison and Cooper [31] successfully sequenced eight genes from a dry pinned specimen of the carabid Bembidion orion Cooper collected in 1968 and used that specimen as a reference in a species delimitation approach. Heintzman et al. [32] amplified mitochondrial and nuclear DNA fragments from several carabid Amara alpina (Paykull) specimens collected between 1875 and 1999. Kanda et al. [33] successfully recovered protein-coding, ribosomal, and mitochondrial genes from one 84-year-old (age before DNA extraction) tenebrionid beetle, and from four to 69-year-old specimens of the carabid beetles Bembidion Latreille and Lionepha Casey to test their phylogenetic position and identify the factors that impact the success of sequencing NHCs specimens. Sproul and Maddison [34] used dry-stored carabid specimens of Lionepha and Bembidion (ca. 159-58 years old) to amplify their mitochondrial genome, nuclear rDNA complex, and 67 low-copy-number nuclear protein-coding genes. Finally, Jin et al. [27] recovered mitochondrial genes from specimens of prionine longhorn beetles that were up to 128 years old, which allowed them to identify new taxa and provide new insights into the phylogeny of this group. All these studies explored DNA preservation in museum beetle specimens and highlighted the importance of NHCs specimens for genetic studies.

Eriopis Mulsant is a South American genus of ladybird beetles (Coccinellidae, Coccinellinae, Coccinellini) currently comprising 23 species [35]. Taxonomic identification at the species level of certain Eriopis is difficult due to similarities in body coloration design and genitalia morphology [36]. For several species and subspecies, only the type series, which may be an old specimen, is known; for others, there are doubts regarding their taxonomic position. Therefore, NGS is an attractive tool to investigate the systematics of this genus, and this study is a first step in this process. While revising Eriopis specimens from several American and European NHCs, we found two historical specimens collected before 1930, which correspond to a new species. The discovery of these two unique and well-preserved samples opened the possibility of DNA sequencing using the Illumina NGS platform. In this study, we (i) describe this new species and compare its morphology with related taxa, (ii) reconstruct and characterize its mitochondrial genome, and (iii) examine its phylogenetic position. 


\section{Material and Methods}

\subsection{Specimens and Taxonomy}

We studied two specimens, designated here as type series, which were preserved dry and glued to a card mount and deposited in the Muséum national d'Histoire naturelle (MNHN), Paris, France. To dissect the male genitalia, the holotype was softened in a wet chamber containing distilled water, after which the abdomen was removed and the tergites and sternites were separated laterally. Dissected genitalia were cleared in a $5 \%$ cold $\mathrm{KOH}$ (Potassium hydroxide) solution and preserved in glass vials containing glycerin. Digital photographs of the genitalia were taken using a Canon EOS 60D Digital SLR camera on a Nikon SMZ1500 stereomicroscope at the MNHN. The genitalia terminology used in this study follows Ślipiński [37]. Holotype dissection was carried out after DNA extraction to avoid losing DNA-containing tissue and altering the quality of the genetic material with the dissection process. After DNA extraction, the re-mounted specimens were photographed with a Canon EOS 6D Digital SLR camera at the MNHN. All measurements of the beetle's body were obtained with the image-processing package FIJI (open source) [38].

The nomenclatural acts resulting from this study follow the International Code of Zoological Nomenclature (ICZN) [39]. This published work and the nomenclatural acts have been registered in the online registration system of ZooBank (http://zoobank.org), following the Life Science Identifiers (LSIDs).

\subsection{DNA Extraction}

First, we cleaned the two specimens and removed them from the mounts following the recommendations of Kanda et al. [33]. Next, we used the non-invasive DNA extraction protocol suggested by Gilbert et al. [18], in which whole specimens (without removing body parts) are used. We observed that after the process of DNA extraction, the only visible external alterations in these Eriopis specimens were a lightening of the yellow spots and the loss of a few tarsi. Total genomic DNA (gDNA) was extracted in October 2018 using a QIAamp DNA Micro Kit (Qiagen Inc.) following the manufacturer's instructions. The quantification of extracted gDNA was performed with a Qubit ${ }^{\mathrm{TM}}$ dsDNA High-Sensitivity (HS) Assay Kit with a Fluorescence Microplate Reader in a $1.0 \mu \mathrm{L}$ sample. Only gDNA extracted from the holotype (sequence code: K22: PA-PA-H-1) was processed for sequencing. gDNA from the paratype (K47: PA-PA-P-2) was stored at $-30{ }^{\circ} \mathrm{C}$ at the MNHN.

\subsection{Library Preparation and DNA Sequencing}

DNA quality and quantity metrics from the previous step were used for library preparation. Genomic DNA was indexed and libraries were prepared using the NEBNext ${ }^{\circledR}$ Ultra ${ }^{\text {TM }}$ II DNA Library Prep Kit for Illumina (New England BioLabs), following the manufacturer's instructions. The preparation of the Adapter Mix and Adapter Fill-In steps were performed as described by Meyer and Kircher [40]. After adapter ligation, the reaction was purified using solid phase reversible immobilization (SPRI) with Carboxyl-coated magnetic beads. Here, we selected fragments ranging from 400 to 500 base pairs (bp). Following the size selection step, real-time PCR (qPCR) (CFX 96 ${ }^{\circledR}$ BIORAD) was conducted to determine the optimal number of amplification cycles for PCR indexing (PCR cycling conditions were initial denaturation at $98^{\circ} \mathrm{C}$ for $2 \mathrm{~min}$ followed by 15 cycles of denaturation at $95^{\circ} \mathrm{C}$ for $30 \mathrm{~s}$, primer annealing at $58^{\circ} \mathrm{C}$ for $30 \mathrm{~s}$, and extension at $72{ }^{\circ} \mathrm{C}$ for $40 \mathrm{~s}$, with a final elongation of $5 \mathrm{~min}$ at $72{ }^{\circ} \mathrm{C}$ ). After PCR indexing, another purification reaction was performed as above. Total gDNA was quantified with a Qubit ${ }^{\mathrm{TM}}$ dsDNA (HS) Assay Kit using Qubit ${ }^{\mathrm{TM}}$ Fluorometer (Life Technologies) in a $1.0 \mu \mathrm{L}$ sample after library preparation. Libraries were quantified with a DNA 1000 series II chip on a 2100 Bioanalyzer (Agilent Technologies, Santa Clara, CA, USA) (High Sensitivity DNA Assay). Pooled libraries were sequenced as 150 paired-end reads on an Illumina HiSeq 3000 HWI-J0015 on a single lane at the Genome and Transcriptome Platform Genotoul (Toulouse, Haute-Garonne, France). 


\subsection{Genome Assembly, Annotation, and Reconstruction}

Sequencing reads from both paired-end libraries were imported in Geneious Prime 2019.1.3 (Biomatters Ltd.); then, low-quality reads and adaptor contamination were trimmed using the BBDuk plugin (minimum quality score of 30 and minimum read length of $30 \mathrm{bp}$ ). Quality and length distribution were inspected using FastQC v. 0.11.8 [41]. Using the "Map to Reference" option in Geneious (custom sensibility, fine tuning: iterate up to 10 times; max. mismatches per read 30), we extracted mitochondrial sequence fragments from the total reads. The mitochondrial genome of Coccinella septempunctata (Linnaeus) (Coccinellidae, Coccinellinae) (GenBank accession number: JQ321839) was used as reference [42]. After removing the reference sequence, de novo assembly (sensibility: high sensibility/medium) was performed in Geneious. The longest resulting contigs were chosen as seeds and were used to map the filtered reads (custom sensibility, fine-tuning: iterate up to 25 times; max. mismatches per read 10). The resulting sequence contigs were used to generate a consensus sequence and create a circular molecule. Cytochrome c oxidase subunit 1 (COX1), Cytochrome b (Cyt B), and small subunit and large subunit mitochondrial ribosomal RNAs (12S and 16S) were submitted to standard nucleotide BLAST (https://blast.ncbi.nlm.nih.gov/Blast.cgi) to corroborate the taxonomic identity of this specimen within Coleoptera Coccinellidae. The identity and position of protein-coding genes (PCGs), transfer RNA (tRNA), and rRNA genes were determined using the MITOS web server (http://mitos.bioinf.uni-leipzig.de) [43]; and tRNAscan-SE 1.21 [44], in combination with visual comparison with the annotated mitogenome of a closely related taxon (C. septempunctata) in Geneious, followed by manual verification. The tRNAs are labeled according to the IUPAC-IUB (International Union of Pure and Applied Chemistry-International Union of Biochemistry) amino acid code. All PCGs were translated (transl_table 5) to confirm the presence of start and stop codons and check for the absence of pseudogenes with the "translate" option in Geneious. Reconstruction of the mitochondrial genome was also performed with Geneious. Nucleotide composition was estimated as percentage and AT- and CG-skews, as $(A-T) /(A+T)$ and $(G-C) /(G+C)$, respectively, where $G$, $\mathrm{A}, \mathrm{T}$, and $\mathrm{C}$ are the frequencies of each nucleotide [45]. The mitochondrial genome was submitted to GenBank with the GenBank submission tool in Geneious.

\subsection{Phylogenetic Analysis}

The phylogenetic position of E. patagonia was inferred from 27 Coccinellidae mitochondrial genome sequences available in GenBank (https:/www.ncbi.nlm.nih.gov/genbank; accessed in 20 January 2020), with Dastarcus helophoroides (Fairmaire) and Gloeosoma sp. used as outgroups (Table 1). The 13 PCGs and the two rRNA genes described above were extracted from each mitogenome and aligned separately with the MAFFT (Multiple Alignment using Fast Fourier Transform) algorithm [46,47] implemented on the online MAFFT server: http://mafft.cbrc.jp/alignment/server/large.html, under the default parameters on the server. The ambiguously aligned regions of $16 \mathrm{~S}$ and $12 \mathrm{~S}$ rRNAs were removed with trimAL v.1.4 [48] using automatic configuration to the heuristic approach. All resulting alignments were checked in AliView [49]. The gene dataset was concatenated with SequenceMatrix [50]. The initial molecular dataset was partitioned a priori in blocks and treated with three partitioning schemes. (1) PCG_RNA (matrix totaling 13,167 nucleotides in length; 41 blocks): one block for each rRNA, and three for each PCG corresponding to each nucleotide position in the codon (including all codon positions); (2) PCG12_RNA (9429 nucleotides in total length; 28 blocks): one for each rRNA and two for each PCG (excluding the third-codon position); (3) PCG_AA (7720 nucleotides in total length; 13 blocks): 13 PCGs were translate into amino acids. The best partitioning scheme and substitution models to each partition scheme were determined with PartitionFinder v2.1.1 [51] according to the Bayesian information criterion (BIC), with linked branch lengths and a greedy search algorithm [52] (Table S1A-C).

The concatenated matrices were analyzed using maximum likelihood (ML) with RAxML (Randomized Axelerated Maximum Likelihood) v8.2.12 [53] and Bayesian Inference (BI) as implemented in MrBayes 3.2.7a [54], which were both performed in the public resource CIPRES Science Gateway V.3.3 (http://www.phylo.org) [55]. RAxML was based on the BIC (with the RaxMl set of models), and the 
GTR (general time reversible) + I (proportion of invariable sites) + G (gamma distribution) substitution model was selected for the subsets proposed by PartitionFinder. The best tree was obtained using a heuristic search implementing 100 random-addition replicates. In addition to the Felsenstein's bootstrap (FB), we implemented the transfer bootstrap expectation (TBE) statistic with 1000 replicates and a $70 \%$ threshold in the BOOSTER web interface (available at https://booster.pasteur.fr). TBE provides a better measurement of branch repeatability or robustness [56]. The BI analysis was based on the BIC (with the MrBayes set of models) and was performed in two independent runs with four MCMC (Markov chain Monte Carlo) chains run for 50 million generations each, sampling values every 1000 generations. A conservative burn-in of $25 \%$ was applied after checking for convergence in Tracer v1.7.1 [57]. We assessed the convergence of the runs by investigating the average standard deviation of split frequencies and Effective Sample Size (ESS) of all parameters. The support of nodes was provided by clade posterior probabilities (PP) as directly estimated from the majority-rule consensus topology.

Graphical representation of the trees were made using iTOL [58] and edited in Omnigraffle 7.2.10 (https://www.omnigroup.com/omnigraffle/).

\subsection{Estimation of Evolutionary Divergence between Sequences}

We compared the level of mitogenome divergence (PCGs and PCGs + rRNAs) between the new Eriopis species and the other Coccinelloidea included in this study (Table 1). Analyses were carried out using the Kimura 2-parameter model. The variation rate among sites was modeled with a gamma distribution (shape parameter $=1$ ). The 1 st, 2 nd, and $3 \mathrm{rd}$ codon positions were included. All positions with less than 95\% site coverage were eliminated; i.e., less than 5\% alignment gaps, missing data, and ambiguous bases were allowed at any position (partial deletion option). Evolutionary analyses were conducted in MEGA X [59,60].

Table 1. Species of Coccinelloidea used in the phylogenetic analysis. Respective GenBank accession numbers of the mitochondrial genomes and references are given.

\begin{tabular}{|c|c|c|c|c|c|c|}
\hline \multirow{2}{*}{ Family Subfamily } & \multirow[b]{2}{*}{ Species } & \multirow[b]{2}{*}{ Author } & \multicolumn{3}{|c|}{ Mitogenome } & \multirow[b]{2}{*}{ Reference } \\
\hline & & & Length (bp) & Partial-Complete + & GenBank Code & \\
\hline \multicolumn{7}{|l|}{ Corylophidae } \\
\hline \multirow{29}{*}{$\begin{array}{l}\text { Corylophinae } \\
\text { Bothrideridae } \\
\text { Bothriderinae } \\
\text { Coccinellidae } \\
\text { Coccinellinae }\end{array}$} & Gloeosoma sp. & & 12,474 & - & JX412843 & Unpublished \\
\hline & Dastarcus helophoroides & (Fairmaire) & 15,878 & + & NC_024271 & [61] \\
\hline & Aiolocaria hexaspilota & (Hope) & 17,549 & + & MK583344 & [62] \\
\hline & Anatis ocellata & (Linnaeus) & 17,092 & + & NC_036272 & Unpublished \\
\hline & $\begin{array}{c}\text { Anisosticta } \\
\text { novemdecimpunctata }\end{array}$ & (Linnaeus) & 15,289 & - & KT876880 & [63] \\
\hline & Calvia champinorum & Booth & 17,575 & - & KX132085 & Unpublished \\
\hline & Calvia decemguttata & (Linnaeus) & 16,425 & - & KX087252 & Unpublished \\
\hline & Cheilomenes sexmaculata & Fabricius & 17,192 & - & KM244706 & [64] \\
\hline & Coccinella septempunctata & Linnaeus & 18,965 & + & JQ321839 & [42] \\
\hline & Coccinella transversoguttata & Faldermann & 15,806 & - & MG584726 & [65] \\
\hline & Coleomegilla maculata & De Geer & 17,516 & - & KJ778881 & Unpublished \\
\hline & Cycloneda munda & (Say) & 14,292 & - & KJ778882 & Unpublished \\
\hline & Cycloneda sanguinea & (Linnaeus) & 15,137 & $t^{*}$ & KU877170 & [66] \\
\hline & Eriopis connexa & (Germar) & 17,652 & + & MG253268 & Unpublished \\
\hline & Eriopis patagonia & Salazar & 16,194 & - & MN509443 & This study \\
\hline & Halyzia sedecimguttata & (Linnaeus) & 15,766 & - & KT780652 & Unpublished \\
\hline & Harmonia axyridis & (Pallas) & 16,382 & - & KR108208 & [67] \\
\hline & Harmonia quadripunctata & (Pontoppidan) & 18,051 & $+*$ & KX087296 & Unpublished \\
\hline & Hippodamia convergens & Guérin-Méneville & 18,419 & + & KX755331 & [66] \\
\hline & Hippodamia variegata & (Goeze) & 17,823 & + & MK334129 & [68] \\
\hline & Coelophora saucia & (Mulsant) & 14,106 & - & MK574678 & [69] \\
\hline & Propylea japonica & (Thunberg) & 15,027 & - & KM244660 & [64] \\
\hline & Propylea sp. & & 15,915 & - & KX132084 & Unpublished \\
\hline & Henosepilachna pusillanima & (Mulsant) & 16,216 & + & NC_023469 & {$[70]$} \\
\hline & $\begin{array}{c}\text { Henosepilacna } \\
\text { vigintioctopunctata }\end{array}$ & (Fabricius) & 17,057 & + & NC_041172 & Unpublished \\
\hline & Epilachna admirabilis & Crotch & 17,445 & $+^{*}$ & MN053053 & [71] \\
\hline & $\begin{array}{c}\text { Subcoccinella } \\
\text { vigintiguatuorpunctata }\end{array}$ & (Linnaeus) & 14,645 & - & KT780695 & Unpublished \\
\hline & Coccidula rufa & Herbst & 10,589 & - & JX412767 & Unpublished \\
\hline & Cryptolaemus montrouzieri & Mulsant & 17,010 & + & KT874575 & [72] \\
\hline Microweiseinae & Coccidophilus cariba & Gordon & 15,343 & + & MN447521 & [73] \\
\hline
\end{tabular}




\section{Results}

Taxonomy

Eriopis Mulsant, 1850.

Eriopis patagonia Salazar, sp. nov.

Figures 1-5.

Type specimens. Holotype: Patagonie [handwritten label]/Eriopis connexa Ger. v. latepicta Frm [handwritten label]/Muséum Paris 1930 Coll. Sicard/ (MNHN EC 10238 or). Paratype: idem. (MNHN EC 10239 ○').

Type locality. Patagonia.

Etymology. The specific epithet refers to the only geographical locality known for the species.

Diagnosis. Eriopis patagonia can be distinguished from the other Eriopis species that share the same geographical distribution by the following characters: body size smaller in E. patagonia (4.3 mm) and Eriopis latepicta Fairmaire $(4.0 \mathrm{~mm})$, and bigger in Eriopis magellanica (Philippi) $(5.4 \pm 0.4 \mathrm{~mm}$, $n=20)$ and Eriopis eschscholtzii Mulsant ( $4.9 \pm 0.3 \mathrm{~mm}, n=20)$; habitus of the body in the lateral view less convex in patagonia, more convex in eschscholtzii and magellanica; matte black color integument in patagonia and shiny integument in latepicta, eschscholtzii, and magellanica; clypeus wider in patagonia and eschscholtzii and narrower in magellanica; body in general with less pubescence in patagonia than magellanica and eschscholtzii; eyes relatively less globular in patagonia, more so in eschscholtzii and magellanica; pronotum with different shape, relatively rounded oval in patagonia, oval in magellanica, and elongated oval in eschscholtzii. Lateral margins of the pronotum are less prominent in patagonia and more prominent in eschscholtzii and magellanica. Pronotal lateral "pits" narrow and shallow in patagonia, intermediate in following eschscholtzii, and relatively wider and deeper in magellanica; pronotum with a small yellow spot in the center of the anterior region in patagonia and magellanica, and with a complete yellow band joining the lateral spots in latepicta and eschscholtzii; the yellow spot of the lateral regions of the pronotum narrow and until the middle in patagonia, wider and extended along the lateral regions in eschscholtzii and magellanica, but in the latter interrupted in the middle; tibiae with few pubescence in patagonia, abundant setae in eschscholtzii and magellanica; elytra with larger punctuation and more abundant micropunctuation in patagonia than in latepicta, eschscholtzii, and magellanica; yellow spots on the discal region present in magellanica (including the darker morphs where they are slightly visible) and eschscholtzii, but not in the darker morph where the elytra are completely black except for a yellow band on the entire marginal edge of the elytra. These yellow spots in the discal region absent in patagonia and latepicta; patagonia is brachypterous and eschscholtzii and magellanica are macropterous; conformation of the male genitalia is different between patagonia, eschscholtzii and magellanica (data unknown for patagonia females and both sexes in latepicta).

Description. Habitus: elongated and relatively flat (Figure 1A,B); body predominantly matte black, with small light yellow spots (color in dry specimens) in the dorsal and ventral part, in general body with relatively few pubescence and abundant micropunctuations and well-marked punctuations (Figure 1A,B and Figure 2A,B). Total length $4.3 \mathrm{~mm}$ (from labrum to posterior tip of the elytra), humeral width $1.4 \mathrm{~mm}$, and at the middle of the elytra $2.01 \mathrm{~mm}$ in width.

Head (Figure 1C,D and Figure 2A,C): $1.6 \mathrm{~mm}$ in length, $1.0 \mathrm{~mm}$ in width (between the eyes); dorsally with abundant micropunctuations, and large and deep punctuations (diameter $227 \pm 2.7 \mu \mathrm{m}$, $n=10$; distance between punctuations $241 \pm 4.5 \mu \mathrm{m}, n=10$ ), and scarce short setae. Labrum black with a yellow anterior border and with scarce short setae; anterior angles rounded and anterior margin almost straight (Figure 1C,D). Clypeus wide and yellow (Figure 1C,D and Figure 2A). Ocular canthus yellow in the middle and darker at the edges; anterior apex almost reaches the edge of the eyes (Figure 2A). Antennae brown light with scape (basal) short and wide, antennomere I (pedicel) shorter than II, II longer than III, and III shorter than IV (Figure 1E). Eyes not-so-globular (Figure 1A-D and Figure 2A). Ligule, menton, and submenton as in Figure 2F,G; ligula, maxillar, and labial palps brown light (Figure 2G). 
A

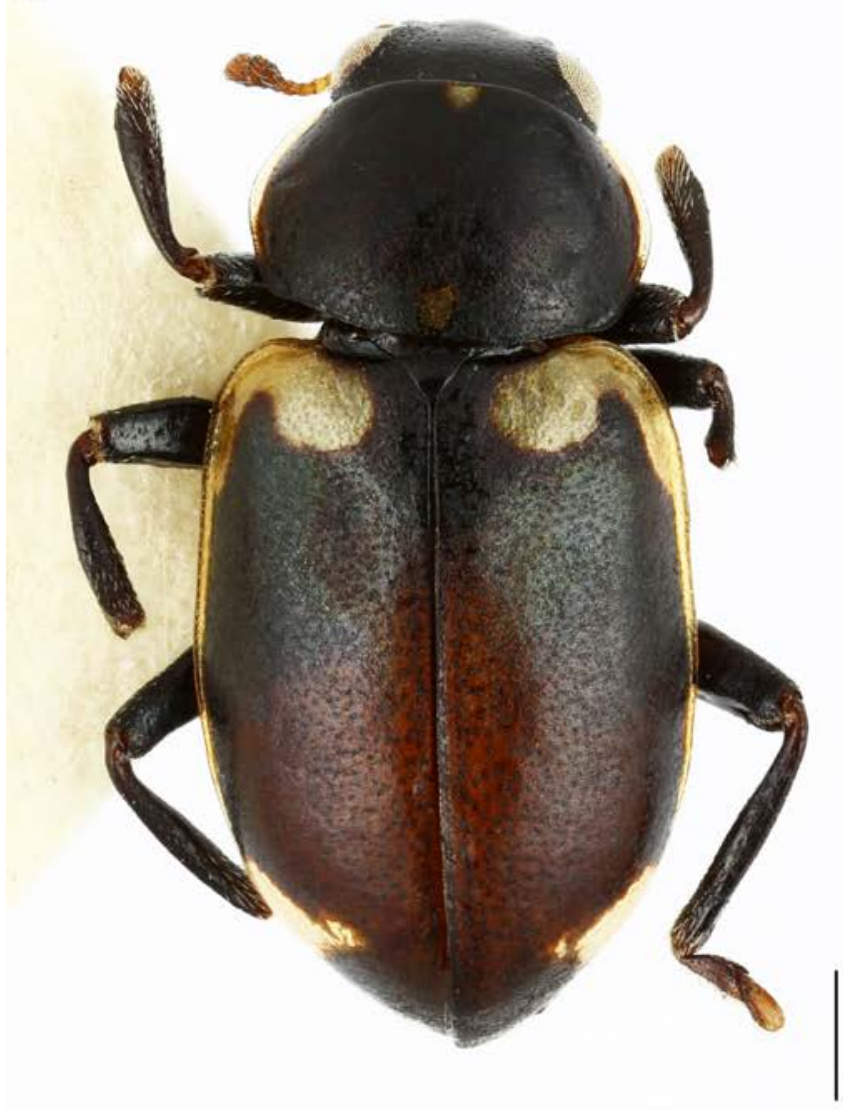

B

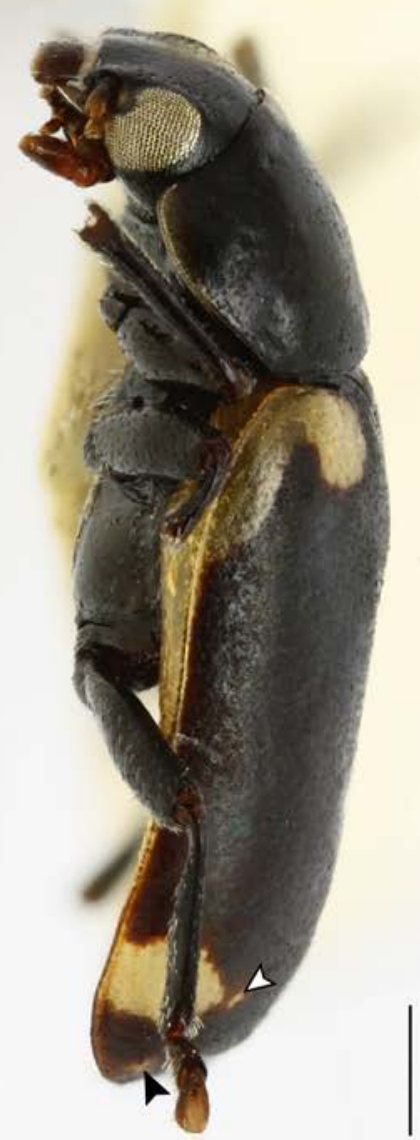

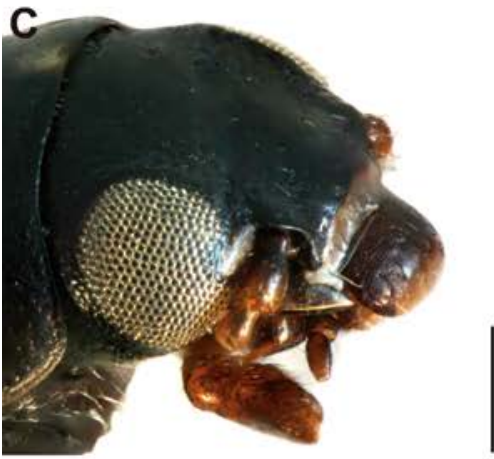

E

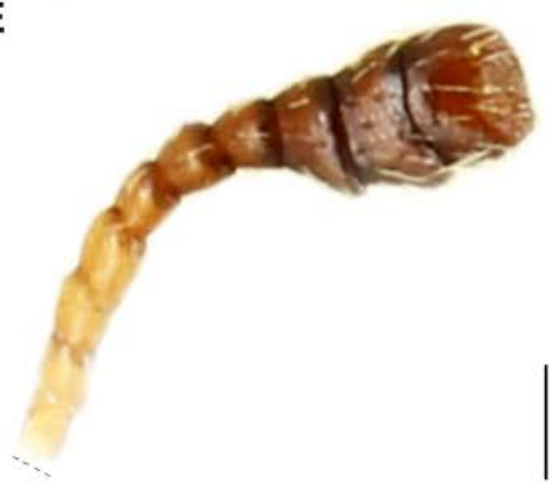

D
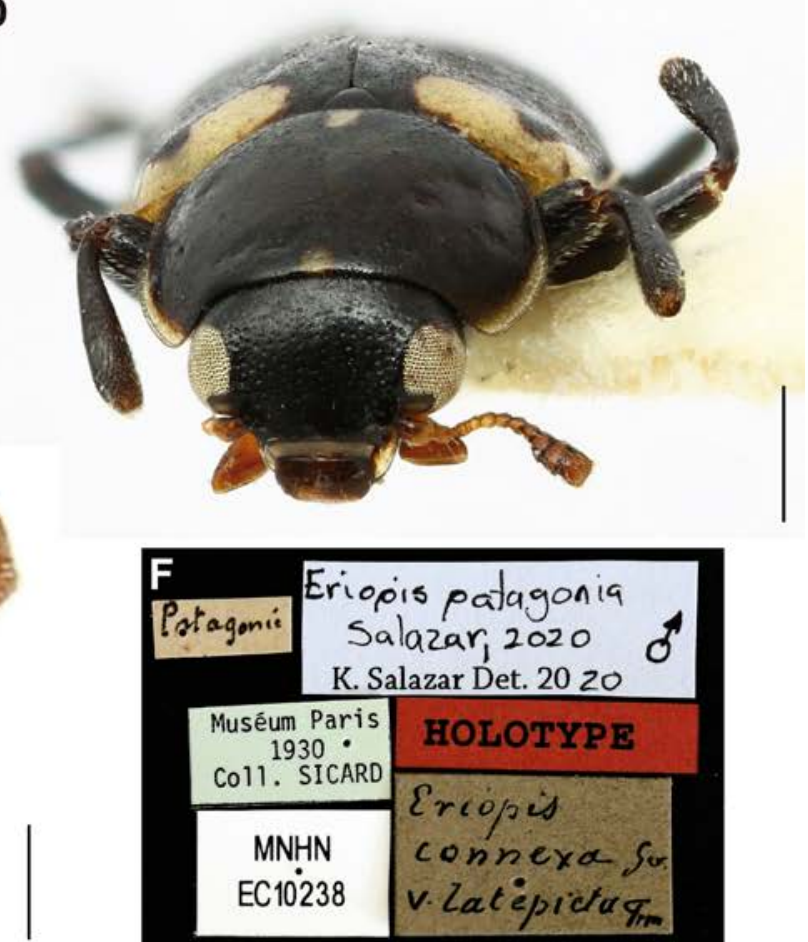

Figure 1. Eriopis patagonia Salazar, sp. nov. - Holotype: dorsal (A), lateral (B,C) and frontal (D) views. (B). The arrowheads signaled the tiny additional spots, which are not present in the Paratype. (E). Antenna with 10 antennomeres (without the basal scape). (F). Labels. Photographs of the specimen were made after DNA extraction. Scale bars (mm): (A-D) 0.5 ; (E) 0.12 . 


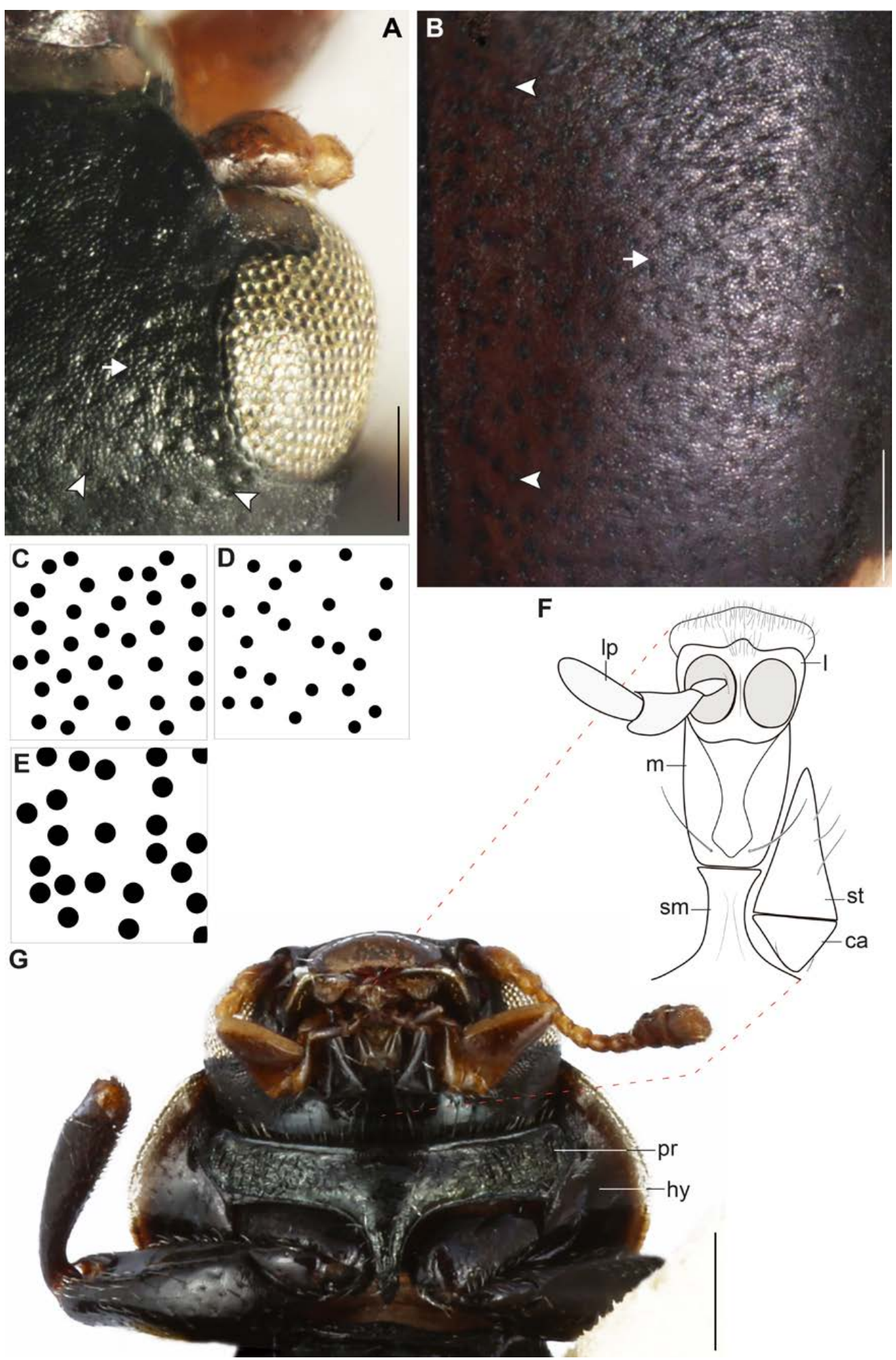

Figure 2. Eriopis patagonia Salazar, sp. nov. - Holotype. (A,C,F,G). Head. (D). Pronotum. (B,E). Elytron. Observe in (A) and (B) the punctuations (arrowheads) and micropunctuations (arrows). (C-E). Dorsal punctuation of the body in squares of $0.25 \times 0.25 \mathrm{~mm}$. Note the difference in the size. (F). Submenton (sm), menton (m), ligule (l), labial palp (lp), cardo (ca), and stipe (st). (G). Ventral view of head and thorax. Dotted lines signal the representation in $(\mathbf{F})$. pr: prosternum; hy: hypomeron. Scale bars (mm): (A,B) 0.12; (G) 0.25 . 
A

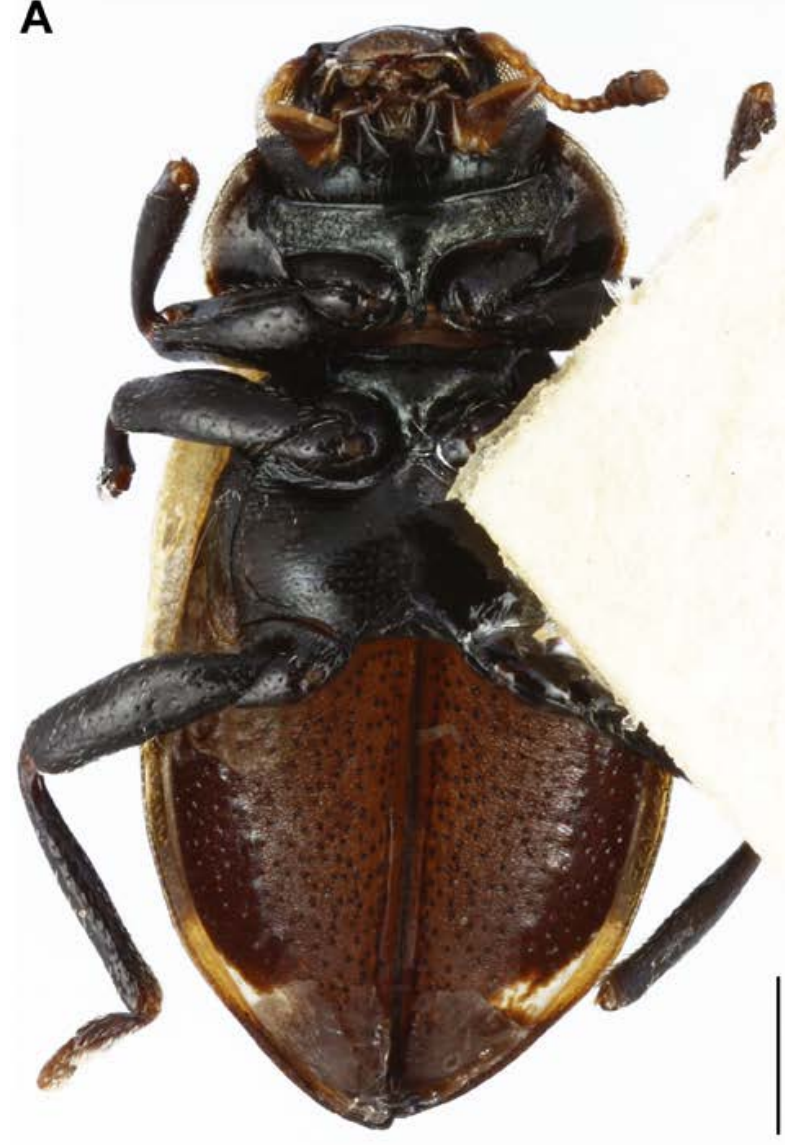

D

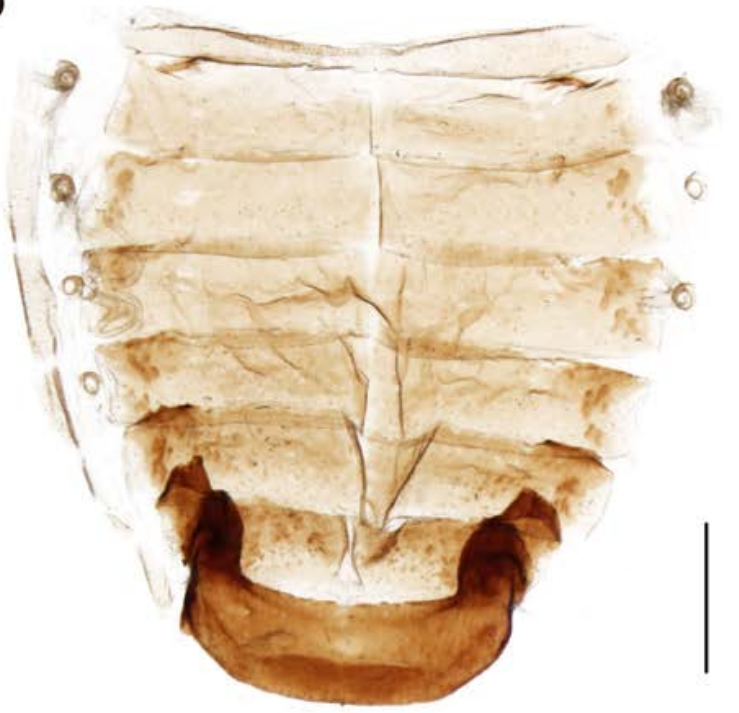

B

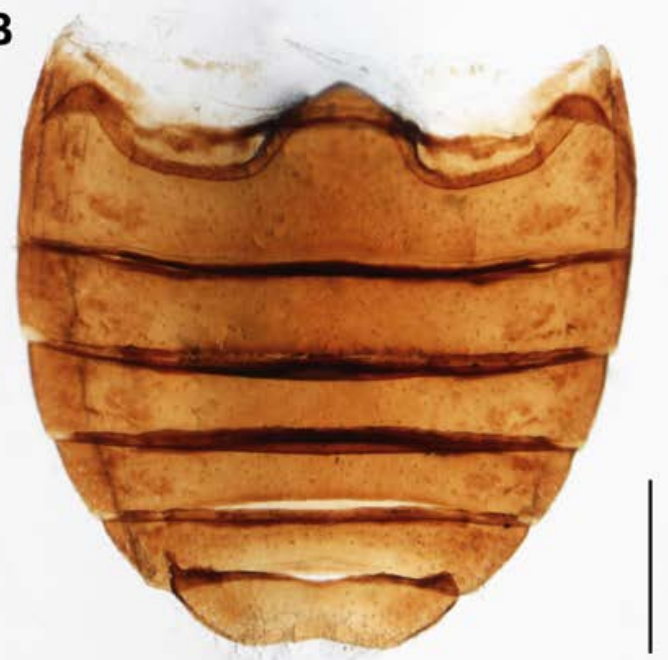

C

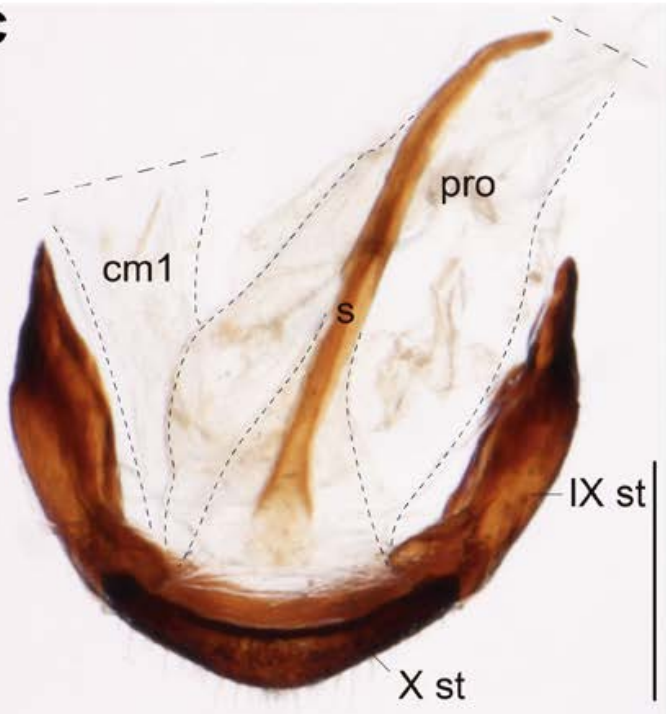

E

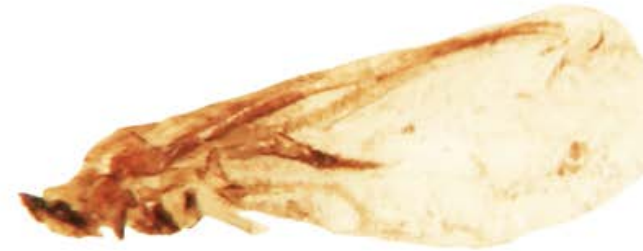

Figure 3. Eriopis patagonia Salazar, sp. nov. -Holotype. (A). In ventral view. (B,C). Sternites (st) III-VIII (B) and IX-X (C). (D). Tergites. cm1: connective membrane 1; pro: proctodeum; s: spicule. (E). Left hindwing. Dotted lines in $(\mathbf{C})$ indicate membrane structures. Scale bars $(\mathrm{mm}):(\mathbf{A}, \mathbf{B}, \mathbf{D})$ 0.5; (C,E) 0.25 . 
A

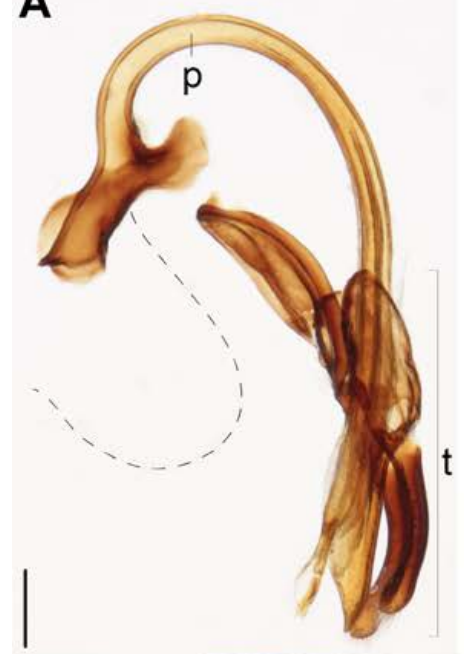

D
B

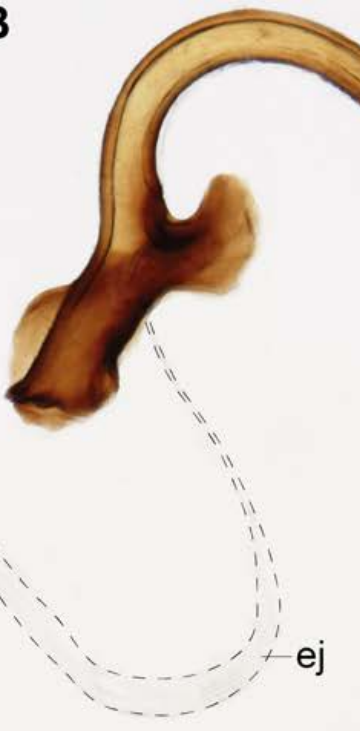

E

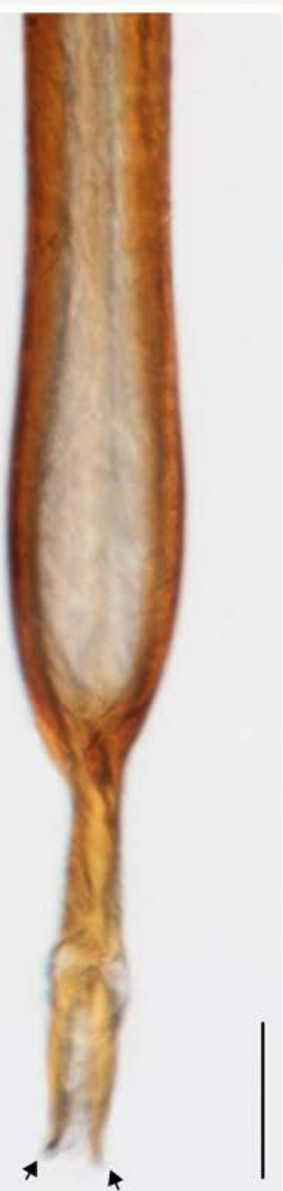

ej
C

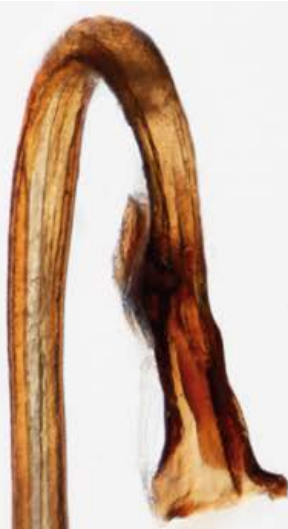

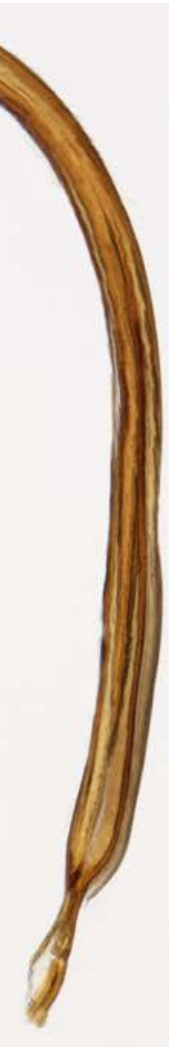

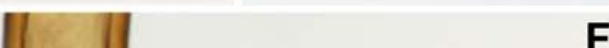

F

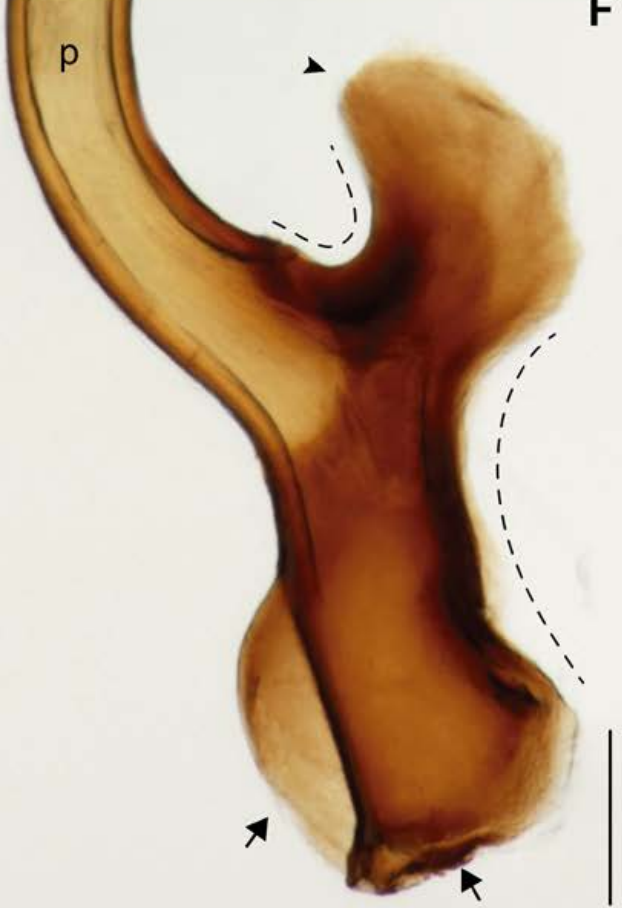

Figure 4. Male genitalia of Eriopis patagonia Salazar, sp. nov. - Holotype: (A,B,D,F) lateral and (C,E) ventral views. (A). Complete genitalia. Compare the relation between the size of the penis (p) and the tegmen $(t)$. (B-F). Penis separated from the $t$. $(D, E)$. The distal region of the $p$. Observe the proportion between the three apical structures (arrows). (F). The most proximal region of the $\mathrm{p}$ (penis capsule). Observe the two lateral extensions: the inner one (arrowhead) and outer one, which is divided into two parts (arrows). ej: ejaculator duct. Dotted lines in (A,B) indicate membrane structures and in (F) concavity formed between the structures. Scale bars (mm): (A-C) 0.25 ; (D-F) 0.12 . 
A

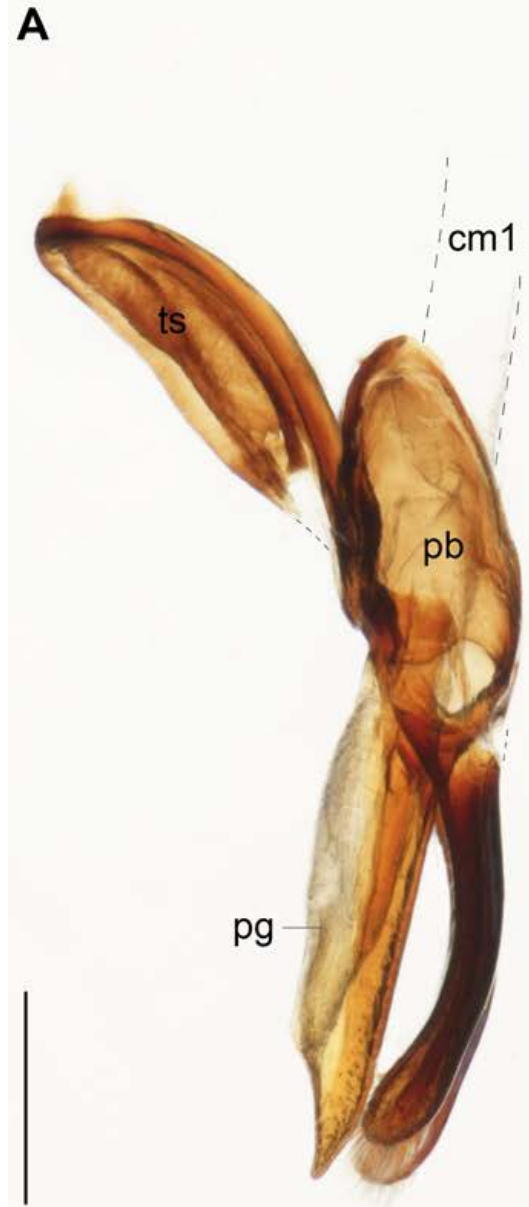

D

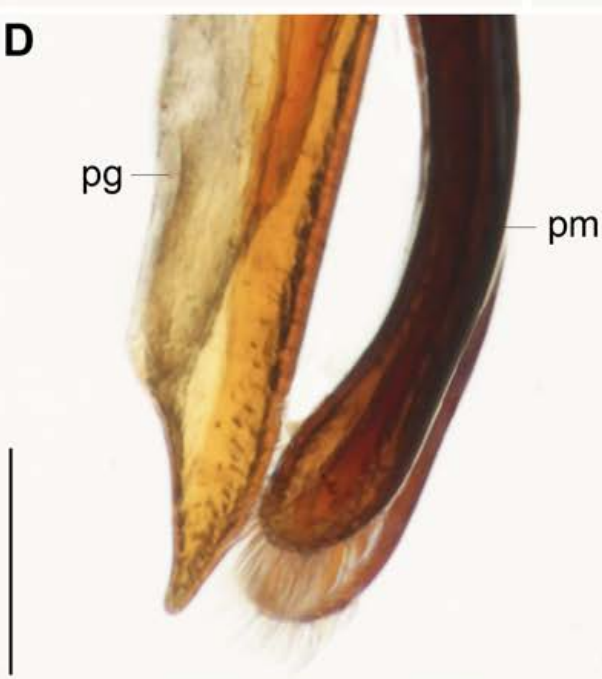

B
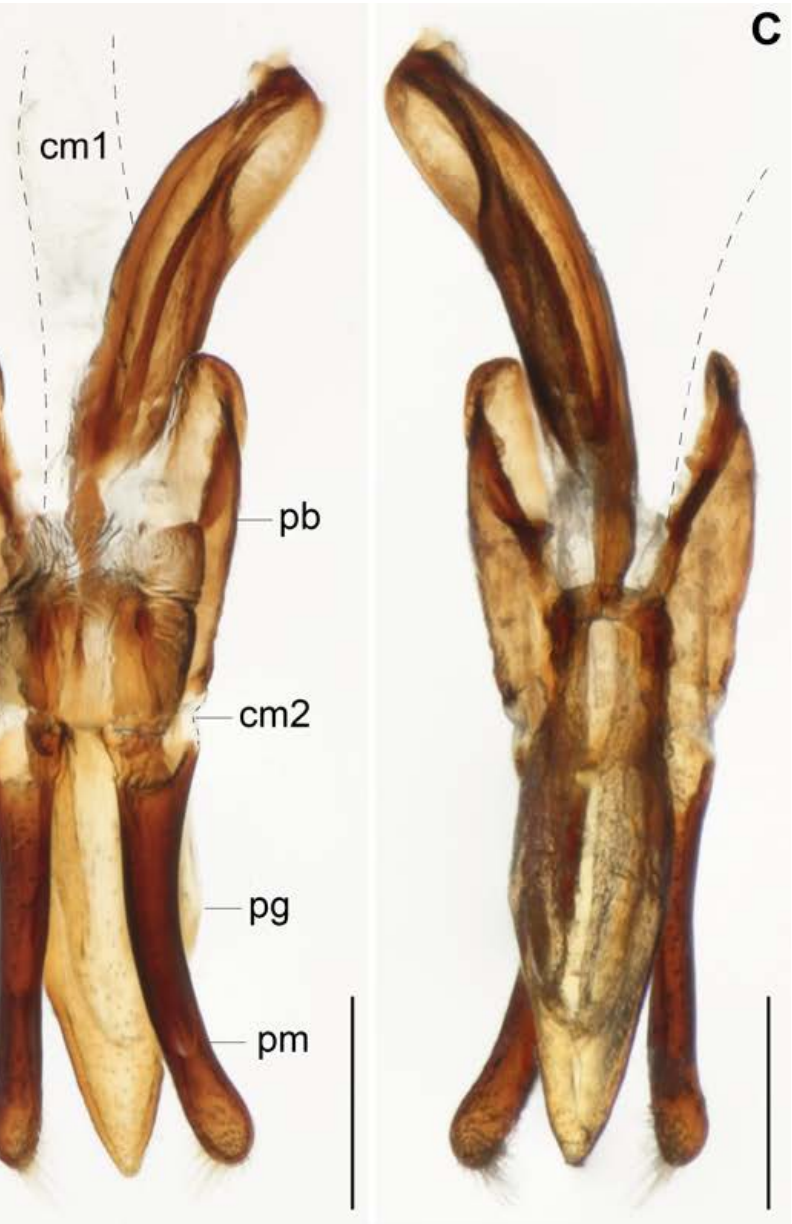

E

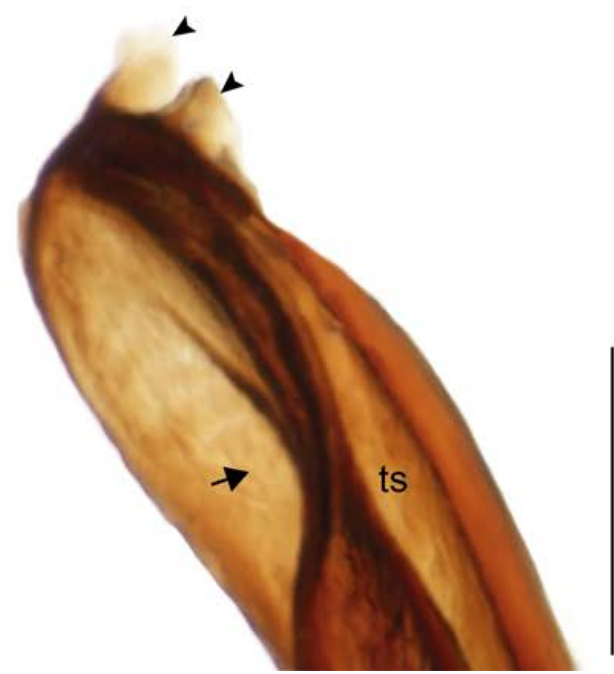

Figure 5. Male genitalia of Eriopis patagonia Salazar, sp. nov. - Holotype. (A-C). Penis guide (pg), parameres (pm), phallobase (pb), and tegminal strut (ts) in lateral (A,D,E), dorsal (B), and ventral (C) views. (D,E). Details of the apical region of the $\mathrm{pm}$ and $\mathrm{pg}$, and basal region of the ts showing the two small prolongations (arrowheads) and the deep concavity in the middle (arrow). cm: connective membrane 1 and 2. Dotted lines in (A-C) indicate membrane structures. Scale bars (mm): (A-C) 0.25 ; (D,E) 0.12 .

Thorax (Figure 1A-D, Figure 2D,G and Figure 3A): Pronotum oval (0.1 mm in length and $1.4 \mathrm{~mm}$ in width at the middle of the pronotum); anterior and posterior margins almost straight, lateral margins rounded, anterior angles rounded and almost level with the anterior margin; dorsal side with one yellow 
small triangular spot in the middle of the anterior region, a yellow spot almost square in the middle of the posterior region, and a yellow spot on the lateral regions from the anterior angle to the middle of the lateral region; pronotal lateral "pits" narrow and shallow (Figure 1A,B,D); thinly punctuate (punctuation diameter $84 \pm 0.8 \mu \mathrm{m}, n=10$; distance between punctuations $163 \pm 1.0 \mu \mathrm{m}, n=10$ ) (Figure 2D). Hypomeron black and narrow (Figures 2G and 3A). Prosternum narrow, in general with scarce short setae but greater in number in the central region (Figures 2G and 3A). Mesepisternum with some short setae to the margin near the mesosternum. Mesepimeron half black and half yellow. Metespisternum with short setae and one small yellow spot in the posterior angle (Figure 3A). Metepimeron narrow and yellow (Figure 3A). Mesosternum with few small punctuations and short setae (Figure 3A). Metaesternum with few and scattered short setae. Elytra (Figure 1A,B, Figure 2B,E, and Figure 3A) dorsally glabrous except the humeri with some short setae, with large and very well-marked punctuations (diameter $249 \pm 2.7 \mu \mathrm{m}, n=10$; distance between punctuations $257 \pm 4.6 \mu \mathrm{m}$, $n=10$ ) and other abundant micropunctuations between the punctuations; epipleura yellow with few short setae; each elytron with a light yellow spot starting from the basal region and continuing to the humeri-marginal region, stretched in the middle. Afterwards, the spot becomes narrower at the margin of the elytra, and near the apical region, it becomes wide again to form another spot, which afterwards narrows toward the apex of the elytra. Legs (Figure 1A,B,D and Figure 3A): femora with few and scattered short setae (dorsal view); tibiae with few short setae; protibiae measure $0.9 \mathrm{~mm}$, mesotibiae $0.9 \mathrm{~mm}$, metatibiae $1.13 \mathrm{~mm}$ in length respectively; tarsi brown. Hindwings reduced (brachypterous; Figure 3E).

Abdomen: Sternites with small punctuation and short setae; shape of the sternites as in Figure 3B,C. Tergites as in Figure 3D. Male Genitalia (Figures 4 and 5): Penis $2.64 \mathrm{~mm}$ in length, tubular and well sclerotized; laterally punctuated and with amber-colored micro-spicules from the middle dorsal region to the distal region, before the apex (Figure 4B-D); apex of the penis, where the gonopore opens narrower and divided into three structures as in Figure 4D,E; the "penis capsule", the most proximal region and most sclerotized part of the penis with two lateral extensions (inner and outer; Figure $4 \mathrm{~F})$. The outer extension $(0.25 \mathrm{~mm}$ in length, $0.15 \mathrm{~mm}$ in width) divided into two asymmetrical parts, and the inner extension $(0.19 \mathrm{~mm}$ in length, $0.21 \mathrm{~mm}$ in width) curved and forms a small concavity $(0.1 \mathrm{~mm}$ in width). Both extensions with a well-marked curve in the base (lateral view; Figure 4F). Parameres (Figure 5A-D) short (0.54 mm in length) with abundant punctuations, well curved (lateral view), run almost in parallel and open slightly in the apical region (dorsal and ventral views); apex well rounded with abundant setae (Figure 5A-D); base strongly concave (dorsal view, Figure 5B). Phallobase (Figure $5 \mathrm{~A}-\mathrm{C}$ ) elongated $(0.45 \mathrm{~mm}$ in length, $0.15 \mathrm{~mm}$ in width, lateral view), almost the same size as the parameres and reaching almost half of the tegminal strut, with the ventral margin irregular and strongly sclerotized. Penis guide (phallus) (0.67 $\mathrm{mm}$ in length, $0.19 \mathrm{~mm}$ in width) with a deltoid shape and the base with a square shape (ventral view, Figure 5C); apex narrower, with abundant punctuations and almost at the level of the apex of the parameres (Figure 5D). Tegminal strut long (0.70 $\mathrm{mm}$ in length) and wide $(0.21 \mathrm{~mm}$ in width), well sclerotized, deeply concave in the middle, and with two small prolongations in the base (Figure 5E).

Variation in body color pattern. The holotype specimen has one tiny spot over the spot that is near to the apical region of the right elytron (Figure 1B), but both spots overlap on the left elytron. There is also another small spot near the apex of the elytra (Figure 1B). The paratype does not have these additional spots. No other morphological variation was observed.

Key characters. Habitus relatively flat; dorsal region of the body with matte black integument; pattern yellow of the elytra present in the humeri-marginal region, marginal region, and apical region, and absent in the discal region; elytra with abundant micropunctuations and large punctuations; pronotum rounded oval with small yellow spots; brachypterous.

Distribution. The label states that this species is distributed in South America, Patagonia Region, without any other specification. 
Nomenclatural remarks and comments. We found these two specimens in Albert Sicard's nominal collection at the MNHN. Sicard identified these specimens as Eriopis connexa Germar v. latepicta Fairmaire. The locality label and the identification label correspond to Sicard's handwriting (Figure 1F). This identification label was found on one side of the specimens inside Sicard's box, which agrees well with his style of organizing boxes. The specimens of E. patagonia do not have an exact collection date, and we have no other indication to infer a precise date. Sicard's collection entered the MNHN in 1930. Thus, these specimens have as a minimum collection age of the date that the Sicard collection entered the MNHN; however, we can assume that the specimens were collected long before 1930. Another complication for dating the specimens is that other people's collections of Coccinellidae entered the museum through Sicard [74].

Next-generation sequencing output. Of a total of 4,147,922 sequenced reads, 3,179,654 reads were retained after trimming the index library and the process of quality control. Of these, 27,612 corresponded to reads from the mitochondrial genome of this species. The mean coverage of the sequenced mitogenome was 142.8 (mean number of sequences covering a column in the assembly).

Genome organization (Tables 2 and 3; Figures 6-8). The circular mitogenome was determined to be 16,194 bp in length. This genome consists of 13 PCGs, two rRNA genes, a single non-coding $\mathrm{A}+\mathrm{T}$-rich region (1768 bp, the A + T ratio is $82.1 \%$ ), and 21 tRNAs. Isoleucine tRNA (tRNA-Ile) was not detected due to incomplete sequencing. The $21 \mathrm{tRNAs}$ have a range length from 60 to $70 \mathrm{bp}$ and compose $1341 \mathrm{bp}$ in total length. In regard to the secondary structure (Figure 8), all tRNA present a canonical cloverleaf secondary structure with the conventional four arms, except the tRNASer ${ }^{1}$, which lacks the D-arm and is replaced by a single loop. The tRNAs Try, Leu ${ }^{2}$, Asp, Arg, and Leu ${ }^{1}$ have a smaller T-loop motif. The tRNAs Cys, Ala, Arg, and $\mathrm{Ser}^{2}$ have a smaller D-loop motif. The general nucleotide composition of this genome is $20 / 79.9 \%$, PCGs $20.8 / 79.2 \%$, tRNAs $20.2 / 79.8 \%$, and rRNAs 17.6/82.4\% GC/AT ratio, respectively, with positive AT-skew and negative GC-skew (Table 3, Figure 7).

Table 2. Summary of Eriopis patagonia mitogenome annotation. The exponent numerals in gene column are used to differentiate each of the two Leucine- and Serine-specifying transfer RNAs (tRNAs) $\left(\mathrm{Leu}^{1}\right.$ and $\mathrm{Leu}^{2}{ }^{2} \mathrm{Ser}^{1}$ and Ser ${ }^{2}$ ); TAA ${ }^{1}$ stop codon is completed by the addition of $3^{\prime}$ A residues to mRNA; (-) stop codon not determined.

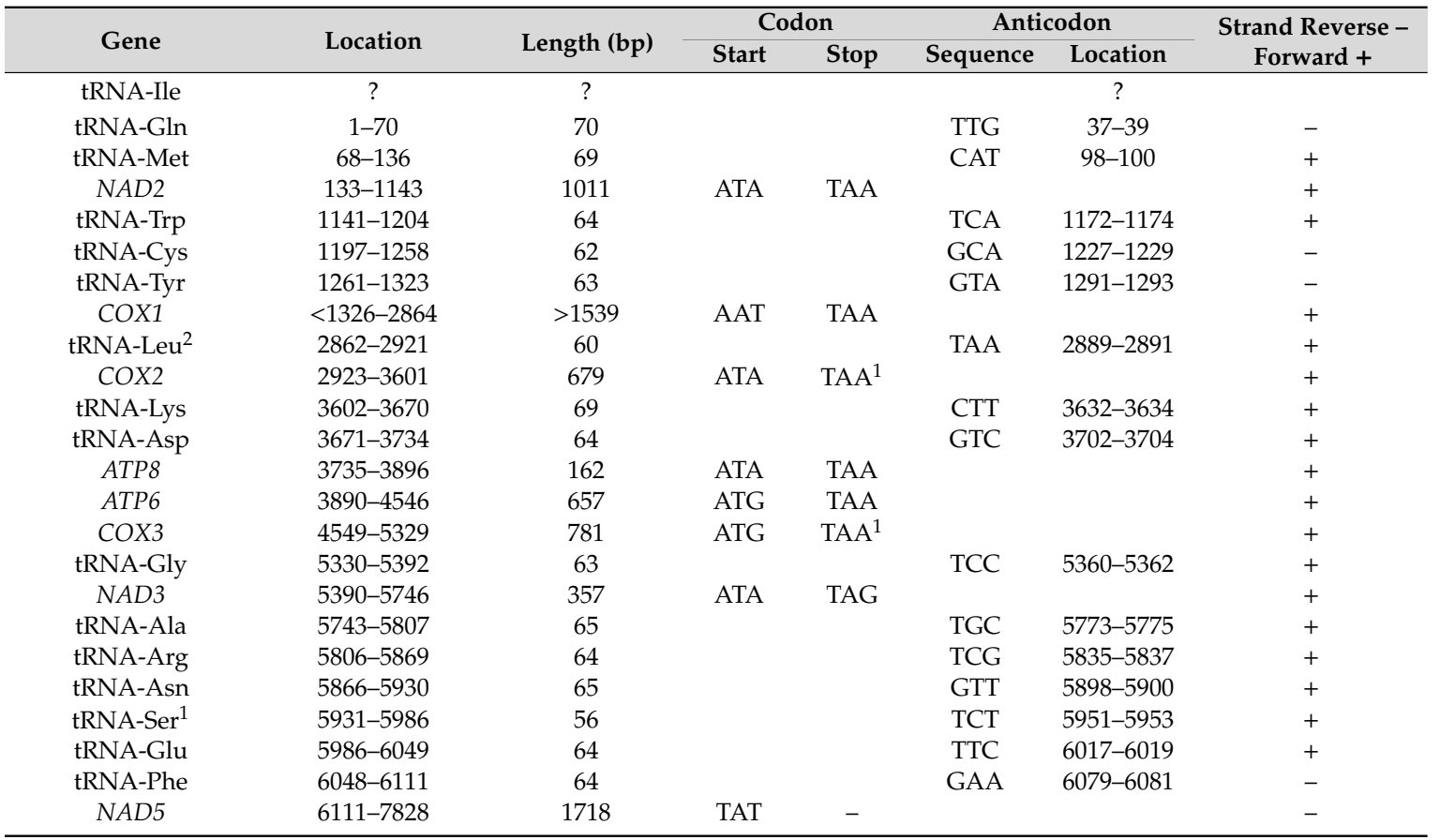


Table 2. Cont

\begin{tabular}{|c|c|c|c|c|c|c|c|}
\hline \multirow{2}{*}{ Gene } & \multirow{2}{*}{ Location } & \multirow{2}{*}{ Length (bp) } & \multicolumn{2}{|c|}{ Codon } & \multicolumn{2}{|c|}{ Anticodon } & \multirow{2}{*}{$\begin{array}{c}\text { Strand Reverse - } \\
\text { Forward + }\end{array}$} \\
\hline & & & Start & Stop & Sequence & Location & \\
\hline tRNA-His & $7826-7889$ & 64 & & & GTG & $7856-7858$ & - \\
\hline NAD4 & 7889-9205 & 1317 & TAT & TTA & & & - \\
\hline$N A D 4 L$ & 9205-9480 & 276 & TAT & TTA & & & - \\
\hline tRNA-Thr & $9482-9545$ & 64 & & & TGT & 9512-9514 & + \\
\hline tRNA-Pro & $9546-9607$ & 62 & & & TGG & 9573-9575 & - \\
\hline tRNA-Ser ${ }^{2}$ & $11,220-11,283$ & 64 & & & TGA & $11,247-11,249$ & + \\
\hline NAD1 & $11,301-12,245$ & 945 & TAT & CTA & & & - \\
\hline tRNA-Leu ${ }^{1}$ & $12,243-12,304$ & 62 & & & TAG & $12,273-12,275$ & - \\
\hline Large subunit $r R N A$ & $12,305-13,580$ & 1284 & & & & & - \\
\hline tRNA-Val & $13,590-13,652$ & 63 & & & TAC & $13,621-13,623$ & - \\
\hline Small subunit rRNA & $13,651-14,426$ & 776 & & & & & - \\
\hline
\end{tabular}

Table 3. Nucleotide composition of the Eriopis patagonia mitogenome. Protein-coding genes (PCGs), transfer RNAs (tRNAs), and ribosomal RNAs (rRNAs).

\begin{tabular}{|c|c|c|c|c|c|c|c|c|c|}
\hline \multirow{2}{*}{ Feature } & \multicolumn{6}{|c|}{ Proportion (\%) } & \multicolumn{2}{|c|}{ Skews } & \multirow{2}{*}{$\begin{array}{c}\mathrm{N}^{\circ} \text { of } \\
\text { Nucleotides (bp) }\end{array}$} \\
\hline & $\mathbf{A}$ & $T$ & $\mathrm{~A}+\mathrm{T}$ & $\mathrm{G}$ & $\mathrm{C}$ & $\mathrm{G}+\mathrm{C}$ & AT & GC & \\
\hline Whole genome & 41.0 & 38.9 & 79.9 & 8.5 & 11.6 & 20.0 & 0.03 & -0.15 & 16,194 \\
\hline NAD2 & 37.6 & 46.2 & 83.8 & 6.9 & 9.3 & 16.2 & -0.10 & -0.15 & \\
\hline COX1 & 32.9 & 39.6 & 72.5 & 13.6 & 13.9 & 27.5 & -0.09 & -0.01 & \\
\hline COX2 & 33.7 & 40.2 & 73.9 & 11.8 & 14.3 & 26.1 & -0.09 & -0.1 & \\
\hline ATP6 & 34.4 & 43.4 & 77.8 & 8.2 & 14.0 & 22.2 & -0.12 & -0.26 & \\
\hline COX3 & 33.5 & 41.9 & 75.4 & 12.0 & 12.5 & 24.5 & -0.11 & -0.02 & \\
\hline NAD3 & 34.5 & 46.2 & 80.7 & 7.0 & 12.3 & 19.3 & -0.14 & -0.27 & \\
\hline NAD5 & 48.5 & 33.2 & 81.7 & 7.0 & 11.2 & 18.2 & 0.19 & -0.23 & \\
\hline NAD4 & 49.4 & 32.8 & 82.2 & 6.9 & 10.9 & 17.8 & 0.20 & -0.22 & \\
\hline$N A D 4 L$ & 51.8 & 33.7 & 85.5 & 4.7 & 9.8 & 14.5 & 0.21 & -0.35 & \\
\hline Large subunit $r R N A$ & 44.2 & 39.1 & 83.3 & 6.0 & 10.7 & 16.7 & 0.06 & -0.28 & \\
\hline Small subunit rRNA & 43.9 & 37.1 & 81.0 & 6.4 & 12.5 & 18.9 & 0.08 & -0.32 & \\
\hline $\mathrm{A}+\mathrm{T}$ rich region & 41.3 & 40.8 & 82.1 & 7.8 & 10.1 & 17.9 & 0.01 & -0.13 & \\
\hline$t R N A s$ & 41.4 & 38.4 & 79.8 & 8.9 & 11.3 & 20.2 & 0.04 & -0.12 & 1341 \\
\hline rRNAs & 44.1 & 38.3 & 82.4 & 6.2 & 11.4 & 17.6 & 0.07 & -0.3 & 2060 \\
\hline
\end{tabular}

Estimation of evolutionary divergence between mitogenome sequences (Tables S2 and S3). The values resulting from the genetic divergence analysis between the paired mitochondrial sequences of Coccinelloidea species evaluated with PCGs vs. PCGs + rRNAs are similar. The ladybird beetle mitogenomes included in this study have a divergence range of $\approx 0.43-0.08$ (number of base substitutions per site; Kimura 2-parameter; rate variation among sites modeled with a gamma distribution). The highest calculated divergence value was between Henosepilachna pusillanima and Coleomegilla maculata, and the lowest was between E. patagonia and E. connexa. These Eriopis species have the least divergent mitogenomes compared to other taxa within a same genus (two representatives of Calvia Mulsant 0.17; Coccinella Linnaeus 0.13; Cycloneda Crotch 0.16; Harmonia Mulsant 0.25; Henosepilachna Li and Cook 0.20; Hippodamia Dejean 0.22; Propylea Mulsant 0.11, respectively). The two outgroups Dastarcus helophoroides and Gloesoma sp. have the highest divergence sequence values in comparison to the Coccinellidae.

Phylogenetic analysis (Figure 9 and Figures S3-S5). The phylogenetic analysis of the 15 mitochondrial markers from 27 additional Coccinellidae species confirms that the sequenced specimen of E. patagonia belongs to the Eriopis genus within the Coccinellini tribe and is sister species to E. connexa. Eriopis is the sister group of Cycloneda (clade E). These results were recovered in all partitioned schemes using ML and BI analyses. 


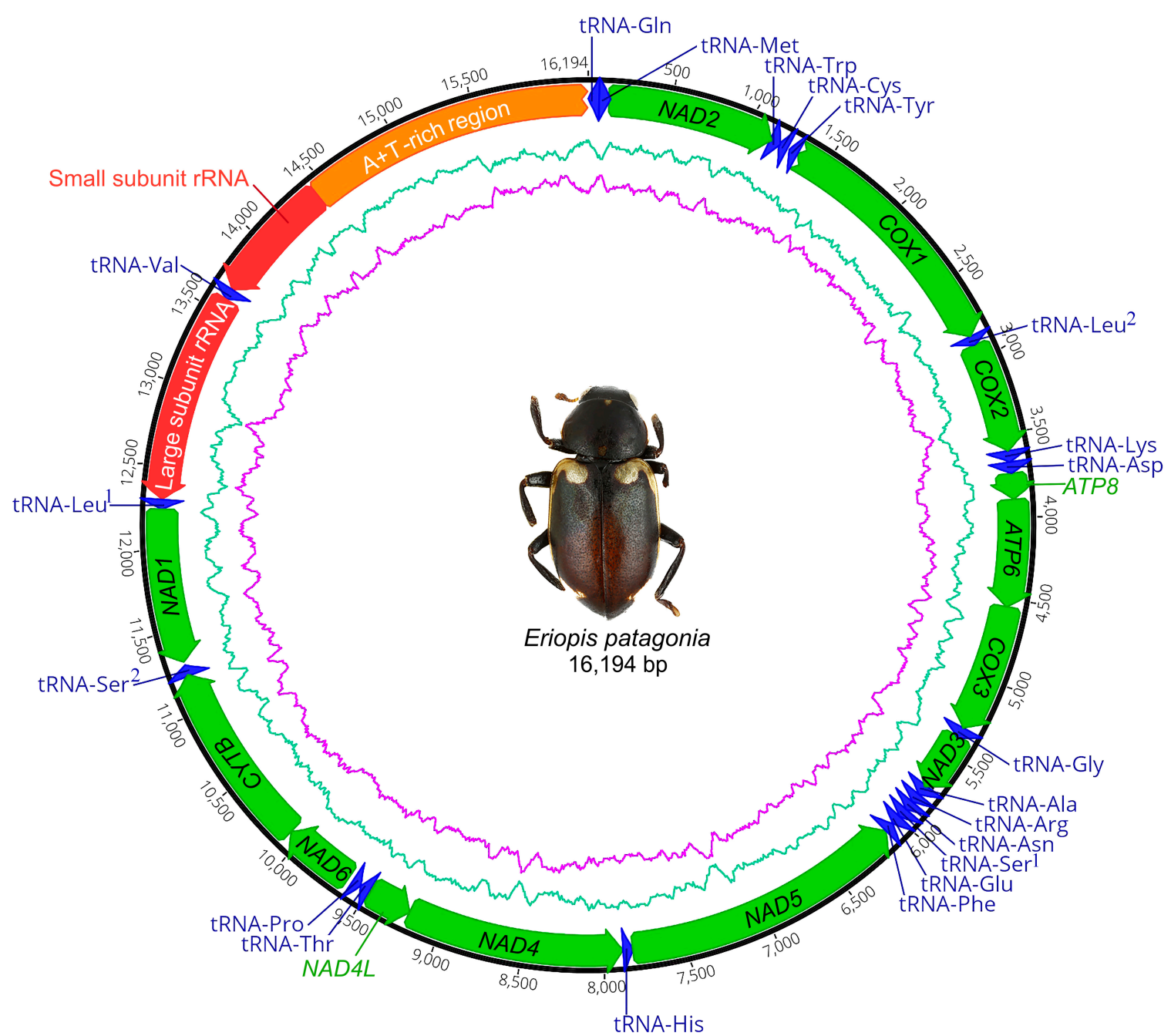

Figure 6. Map of the mitochondrial genome of Eriopis patagonia Salazar, sp. nov. The 13 protein-coding genes (PCGs) are shown in green, the 21 transfer RNA (tRNAs) are shown in blue, the two ribosomal RNA (rRNAs) are shown in red, and the $\mathrm{A}+\mathrm{T}$ rich region is shown in orange. The direction of transcription is indicated by an arrow. Graphic representation of AT (green-blue) and GC (pink) content $(\%)$ and their changes throughout the mitogenome.

In regard to the phylogeny of Coccinellidae, both BI and ML analyses based on 13 mitochondrial protein-coding genes (including all codon positions), 12S rRNA and 16S rRNA (partition PCG_RNA) obtain the same topology (Figure 9 and Figure S3). Most of the clades in these phylogenetic inferences are supported by high support values $(\mathrm{FB}>70$; $\mathrm{TBE}>88$; $\mathrm{PP}>0.99$, respectively), with exception of the clade (Anatis Mulsant + ((Coelophora + Propylea $)+$ Calvia $))(\mathrm{FB}=43 ; \mathrm{TBE}=89 ; \mathrm{PP}=0.9)$. The phylogenetic trees recovered from the concatenated datasets with the two first partitioning strategies (PCG_RNA, PCG12_RNA) and inferred using ML and BI methods showed consistent topologies and similar nodal support values (Figure 9 and Figure S4). The clade (Anatis $+(($ Coelophora + Propylea $)+$ Calvia $))$ has higher support $(\mathrm{FB}=90 ; \mathrm{TBE}=98 ; \mathrm{BB}=1)$ in the second partitioning strategy (Figure S4). The third partition scheme (PCGs_AA, translated into amino acids; Figure S5) produced a variant of the ML tree topology with Anatis found to be sister to Halyzia Mulsant, with a moderate support value (FB = 70; $\mathrm{PP}=0.92)$, and the clade Cryptolaemus Mulsant + Coccidula Kugelann was not recovered as sister of the Epilachnini clade. The basal node of the D and F clades has relatively lower support values $(\mathrm{FB}=71$; 48 , respectively), and the basal node of the B clade has a higher support $(\mathrm{FB}=90)$. In addition, the $\mathrm{BI}$ analysis from this partition scheme does not recovery several of the clades. 


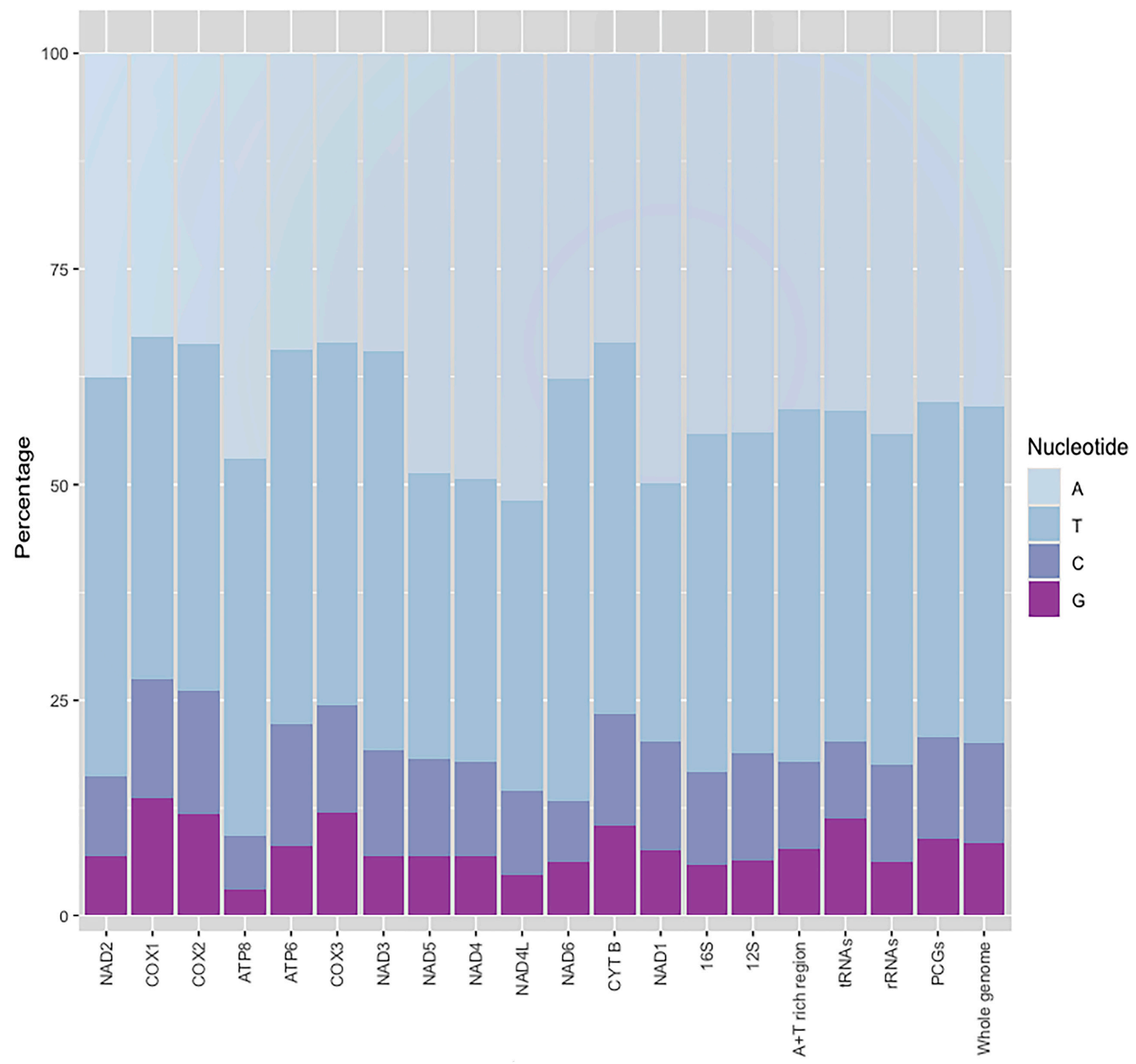

Figure 7. Nucleotide composition of the Eriopis patagonia mitogenome. Protein-coding genes (PCGs), transfer RNAs (tRNAs), and ribosomal RNAs (rRNAs). 

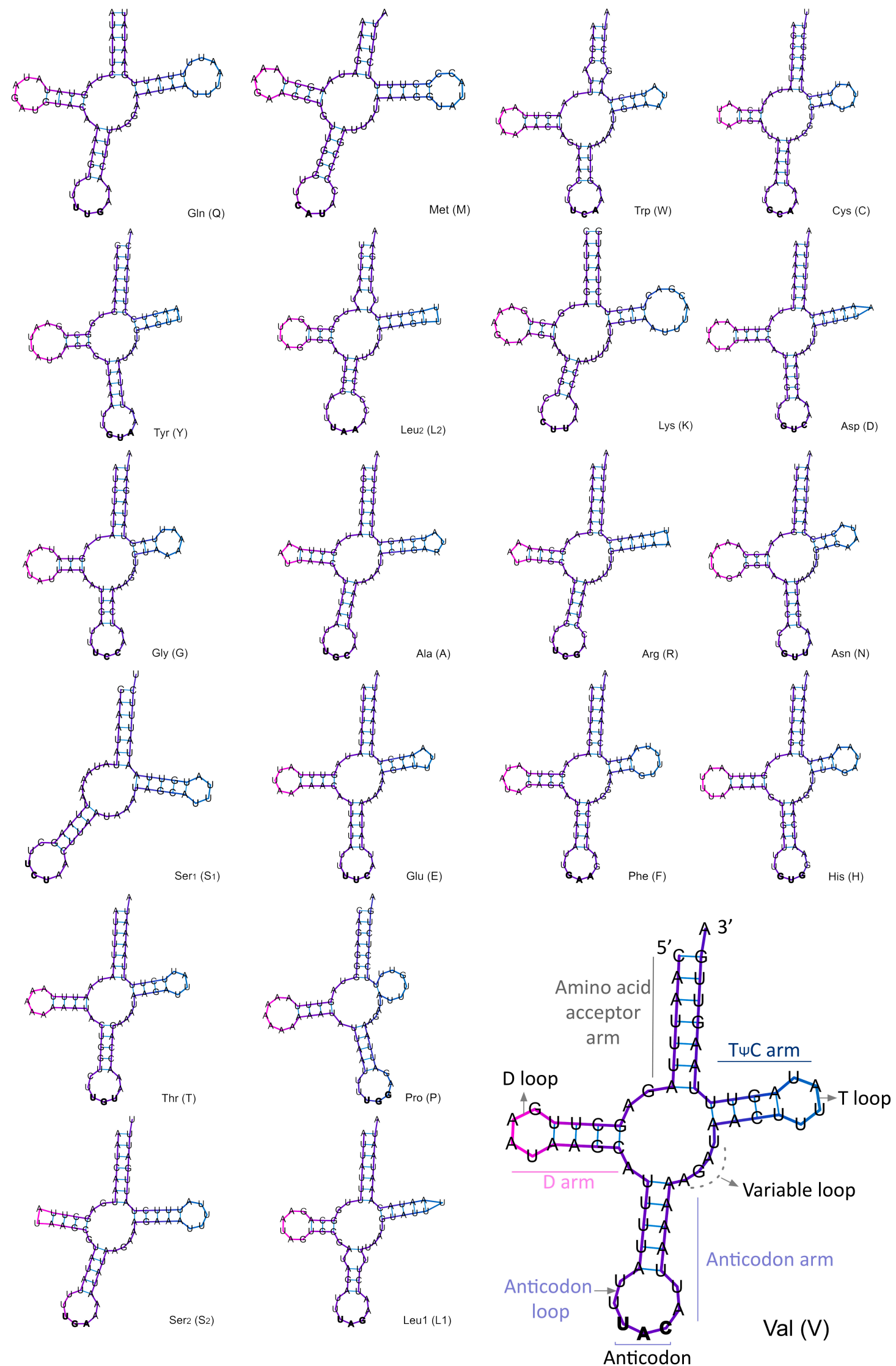

Figure 8. Predicted secondary structure of 21 transfer RNAs (tRNAs) of Eriopis patagonia mitogenome. Bars indicate Watson-Crick base pairings. 


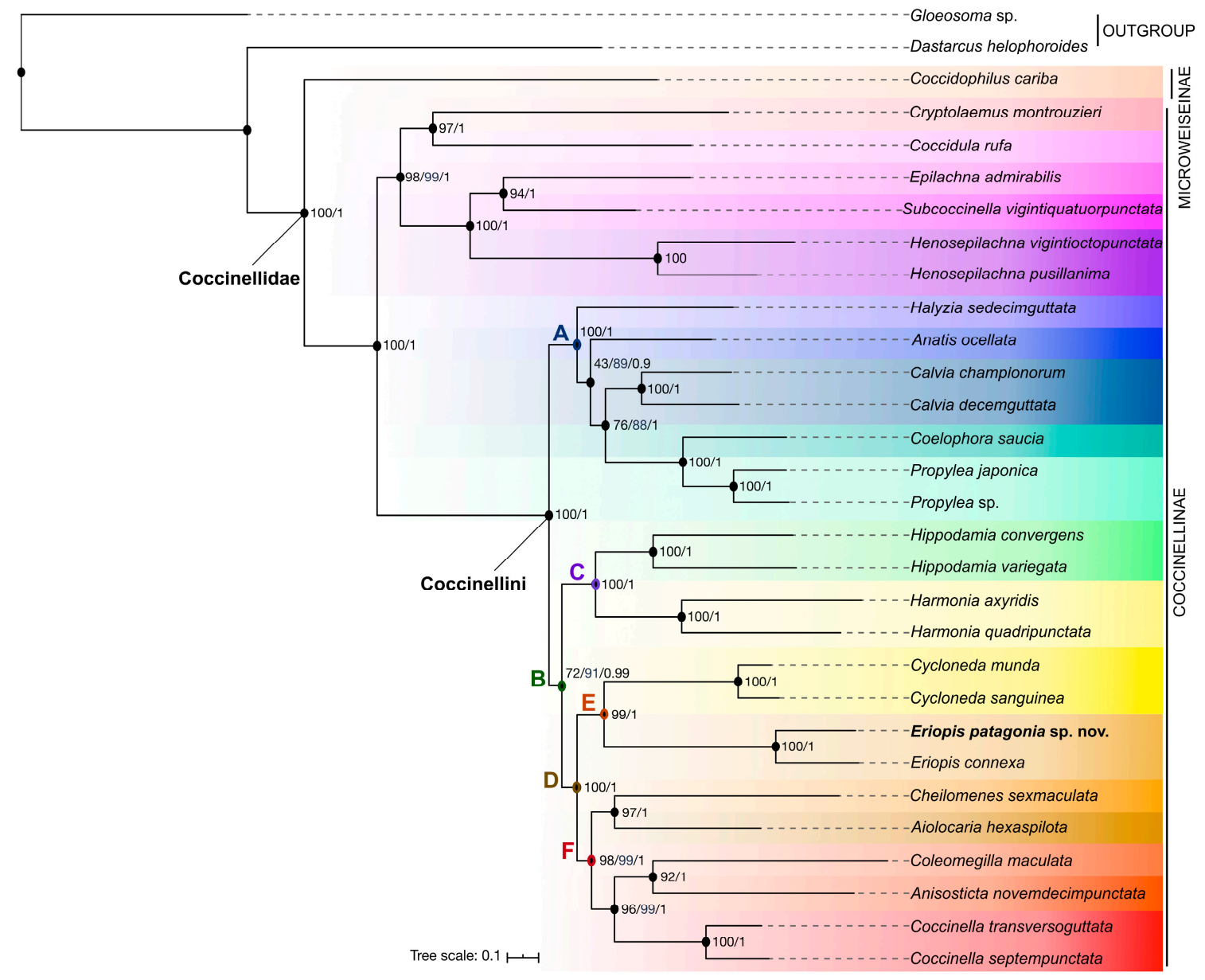

Figure 9. Phylogenetic relationships of Coccinellidae. Tree inferred by the maximum likelihood estimation method (ML) based on 13 protein-coding genes (including all codon positions) and two ribosomal RNAs from mitochondrial genomes of 28 Coccinellidae and two out-groups. ML bootstrap support and posterior probability values are indicated at the right of each node. Transfer bootstrap expectation value (blue) is only shown when it differs from the bootstrap value.

\section{Discussion}

We combined museum genomic and morphological studies to describe a new species of ladybird beetle. With the discovery of the only two known specimens of E. patagonia, we were able to use non-destructive molecular techniques and next-generation sequencing to characterize its mitochondrial genome and infer its phylogenetic position.

\subsection{Morphological Considerations and Geographical Distribution}

Eriopis patagonia is morphologically very close to E. latepicta. Based on the brief description of E. latepicta by Fairmaire [75], the most relevant characters that differentiate these species are the habitus of the body (flat vs. convex), punctuation of the elytra, integument brightness and the extension of the light spot on the anterior region of the pronotum. Eriopis patagonia has only a tiny spot in the central part of the anterior region of the pronotum, while in E. latepicta, a yellow band completely covers the anterior region and joins with the lateral spots of the pronotum. This feature of the pronotum can be polymorphic or not in other Eriopis species. For example, all morphotypes of E. eschscholtzii have an entire yellow band on the anterior region joining with the lateral spots of the pronotum. Eriopis concordia González has an entire band on the anterior region of the pronotum that continues into the lateral region; however, some specimens only have a spot in the central part of the anterior region that does not join with the lateral spots. In Eriopis loaensis González, the situation is opposite to that of 
E. concordia, whereby most specimens have only one spot on the anterior region of the pronotum and a few have a yellow band [36].

A key character distinguishing E. latepicta and E. patagonia is the punctuation of the elytra, which generally does not vary intraspecifically. The former has very small punctuations, whereas the latter has larger and marked punctuation and abundant micropunctuation. In addition, Fairmaire [75] mentioned that E. latepicta has a shiny black color and that it could have (but he did not affirm this) two spots on the discal region of the elytra. The new species has a matte black color and has no clear spots in the discal region of the elytra. These two discal spots are generally common in most species of Eriopis. Some Peruvian species (Eriopis santiagoi Bustamante \& Oroz, Eriopis lawalawani Bustamante, González \& Oroz) with a predominance of black coloring in the elytra have one discal spot in each elytron [76]. In the light of the description of E. latepicta, this species and E. patagonia share almost the same elytra coloration pattern. Unfortunately, we cannot compare its other morphological characters with those of E. patagonia because neither we nor anybody else have yet located the type series of E. latepicta studied by Fairmaire. Eriopis latepicta is a species that continues to have an uncertain taxonomic status.

The type locality of E. patagonia is Patagonia, which is a wide region between Argentina and Chile in the south of South America. In the same way, Patagonia is mentioned as the type locality of E. latepicta [75]. This is one of the reasons why we believe that Sicard identified the specimens of the new species as E. latepicta. We suggest that Eriopis patagonia was probably collected somewhere in western Patagonia toward the Andes, because it is a brachypterous species. Increases of certain factors (e.g., wind, cold, geographical isolation) at high altitude have been correlated with wing reduction in other Coleoptera (e.g., Carabidae reviewed by [77]; Passalidae [78]). Thus, it is unlikely that E. patagonia was collected from flat areas in the eastern part of this region.

Two other species of Eriopis have been reported in Patagonia. Eriopis eschscholtzii and E. magellanica are morphologically distinct from E. patagonia. These two species, in addition to the typical black coloration patterns with yellow spots, include specimens with predominantly black coloration, which could be confused with E. patagonia. The "darkest" morph of E. eschscholtzii has completely black elytra, except for the presence of a yellow band along the margin of the elytra. The most common morphotypes of E. eschscholtzii have elytra with large yellow spots, which are sometimes joined together as a band and where the black is reduced [36,79]. The "darkest" morph of E. magellanica has very reduced yellow spots, but these are slightly visible in the discal region of the elytra. In this study, we included other external characteristics of the body besides color pattern, which are useful for distinguishing these species. In regard to the distribution, the darkest morphs of E. eschscholtzii have been reported in the Zona Austral of Chile [36]. In this geographical zone, a specimen was reported in El Valle del Lago Blanco, Río Senguer Department, Chubut Province, Argentina [80] and another was discovered in the XI Region, Balmaceda collected in 1999 and deposited in the personal collection of Manuel Diéguez, Santiago de Chile (http://www.coccinellidae.cl, accessed in 16 June 2018). The darkest morphs of E. magellanica have been reported in Tierra del Fuego, Chile (material observed by us) and Tierra del Fuego, Gallegos Chico, Última Esperanza, Parque Nacional Torres del Paine, Chile (http://www.coccinellidae.cl, accessed in 16 June 2018).

\subsection{Genome Organization}

We sequenced and assembled the mitogenome of one historical and nomenclatural type specimen of E. patagonia. It is the first published and characterized mitogenome for this genus obtained from an old specimen from a Natural History Collection. The order and orientation of the genes in the mitogenome of E. patagonia are consistent with those of other mitochondrial genomes of Coccinellidae [42,62-73] and contain the typical set of mitochondrial genes found in insects.

The predicted secondary structure and anticodon sequence for 21 tRNAs of the E. patagonia mitogenome is similar that reported to other ladybird beetles [65,71]. As was also noted by [65], the most variations are in substitutions, and indels (insertion, deletion of bases) of the tRNA among 
the Coccinellidae are present in the variable and D loops, and $T \psi C$ arm, which is reflected in the differences in the size of this arm and its D-loop. Eriopis patagonia share with Aiolocaria hexaspilota, Calvia muiri (Timberlake), C. septempunctata, Illeis cincta Fabricius, and Propylea japonica a lack of the $\mathrm{T} \psi \mathrm{C}$ arm in tRNA-Pro, which is replaced by the loop [71], while in other species, the T $\psi \mathrm{C}$ arm is present in this tRNA [65]. The Eriopis patagonia mitogenome has the smallest D-loop in tRNA-Try and tRNA-Leu ${ }^{2}$ in comparison with the other studied ladybird beetles where the secondary structure of mitochondrial tRNAs was predicted.

Regarding the species of this genus, E. patagonia and E. connexa (GenBank section number MG253268; unpublished mitogenome) share high similarity in the organization and genetic composition of their mitochondrial genomes (Figures S1 and S2B). Furthermore, both sequenced mitogenomes have the lowest genetic divergence (compared to the divergence values between all taxa of ladybird beetles and species of a same genus analyzed here; Tables S2 and S3). The differences were sequence length (E. patagonia 16,194 bp vs. E. connexa 17,652 bp in length) and nucleotide composition in whole mitogenome, PCGs, tRNAs, and rRNAs (see Figure 7, Table 3 to E. patagonia vs. E. connexa: 20.6/79.5; 21.2/78.8; 21.6/78.4; 17.8/82.3\% GC/AT ratio, respectively; Figure S2B).

The secondary structure and composition of nucleotides of the most mitochondrial tRNAs are highly conserved between both Eriopis species. We noted differences in the sequences and structures of T and D loops in some tRNAs (Asp, Arg, Asn, Glu, Thr, Pro) (Figure 8 and Figure S2A). Based on the prediction by MITOS, particularly the tRNA-Gln in E. connexa mitogenome differs in the sequence of the amino acid acceptor arm and the lack of the T $\psi \mathrm{C}$ arm and typical T-loop (Figure S2A). The latter could be evaluated with other bioinformatics tools available for identifying mitochondrial tRNAs. Although there are exceptions, the most typical in almost all metazoic mitochondrial tRNAs is to have a canonical structure of clover leaves, save for the missing D-arm in the tRNA-Ser [81,82].

The E. connexa mitogenome has an A+T-rich region of $1747 \mathrm{bp}$ in length with 13.8/86.2\% GC/AT ratio. Downstream of this region is tRNA-Ile, which is separated from tRNA-Gln by a 1382 bp-long intergenic spacer. Sequencing failed to recover this intergenic spacer and tRNA-Ile in E. patagonia; however, most if not the entire control region was recovered (1768 bp; 17.9/82.1\% GC/AT ratio). This intergenic spacer, which varies in length, is present in other ladybird beetles [71] and could be present in the mitogenome of other Eriopis species.

The size of the E. patagonia mitogenome is similar to that of other Coccinellini (see Table 1; e.g., Anisosticta novemdecimpunctata, Calvia decemguttata, Coccinella transversoguttata, Halyzia sedecimguttata, and P. japonica). All mitochondrial genomes of these Coccinellini were determined to be partial mitogenomes because that tRNA-Ile (Isoleucine) was not recovered from the genomic library. The largest complete mitogenome in Coccinellidae was reported in C. septempunctata with a total length of $18,965 \mathrm{bp}$, which includes a larger control region of $4469 \mathrm{bp}$ [42]. Other species with complete mitochondrial genomes have a relatively short control region-for example, the $A$. hexaspilota mitogenome with a total length of 17,549 bp and $1603 \mathrm{bp}$ corresponding to the A+T-rich region [62], Harmonia quadripunctata with 18,051 bp and 2071 bp (unpublished), and Hippodamia variegata 17,823 bp and 1590 bp [68], respectively. In general, differences in the length of the control region and the lack of the first transfer RNA in the assembled mitogenomes may be due to the fact that this region has a low recovery.

\subsection{Phylogenetic Considerations}

Our phylogenetic analysis based on mitochondrial genomes (13 PCGs + two rRNAs) from 28 Coccinellidae recovered two main clades (Coccinellinae and Microweiseinae). Coccinellinae is also divided into two main clades (clade Coccinellini and the other clade including Coccidulini, Epilachnini, Scymnini) with high support (PCG_RNA and PCG12_RNA: FB and TBE = 100; PP = 1.0/PCG_AA: $\mathrm{FB}=67 ; \mathrm{PP}=0.84$ ). The generic composition between the main clades and inside each clade of Coccinellini (here A-F) differs slightly to the previous studies of Escalona et al. [83], which includes one mitochondrial and four nuclear markers that Song et al. [71] and Yuan et al. [65] based on complete mitochondrial genomes. Regarding the main clades within Coccinellini, here, this tribe is divided into 
two principal clades ( $\mathrm{A}$ and $\mathrm{B}$, the latter including clades $\mathrm{C}$ and $\mathrm{D})$, as also recovered by Song et al. ([71]; Figures 3 and 4). Contrarily, in Escalona et al. [83], the clade "1" (where is the clade E) was recovered as the early-diverging clade of Coccinellini and being sister to the clade that includes the clades " 2 " and " 3 ". The clade " 3 " is split in two clades (here A and C) that are closely related, while in our analysis, the clade C was sister to clade D. Here, clade D comprises clades " 1 " and " 2 " of Escalona et al. [83]. In Song et al. ([71]; Figure S5), the close relationship between clades A and C was recovered when the gene dataset includes 13 PCGs excluding the third-codon positions combined with the 24 RNA genes using ML analysis.

The phylogenetic relationships between the genera within clade A were almost the same as in Song et al. [71], except for the position of Epilachna Chevrolat, which was found to be sister to Subcoccinella Agassiz. The only difference with the results of Escalona et al. [83] is that Anatis and Halyzia were not sister genera. However, both genera were recovered to be sister when our phylogenetic analysis includes only the mitochondrial PCGs that translate into amino acids. The close relationship between Hippodamia and Harmonia (clade C) was also recovered in previous studies [71,83].

Our analysis also confirmed the close phylogenetic relationship between the South American genera Eriopis and Cycloneda (clade E). The latter has a wider distribution than Eriopis, and it is found from North to South America, including the Caribbean [84]. This result has already been proposed by ([71]; Figure 4) and [83]. However, in the first study, this relationship was not recovered when the dataset included PCGs with all codon positions combined with the 24 RNA genes ([71] Figure 3).

In clade F, we found Cheilomenes Chevrolat as sister to Aiolocaria (Hope), whereas Cheilomenes was found to be more closely related to Anisosticta Chevrolat in previous studies [65,71]. In agreement with Escalona et al. [83], we found Coleomegilla Timberlake to be sister to Anisosticta. In our study, Coccinella was nested within clade F, as also proposed by Song et al. ([71]; Figure 4 and Figure S5). However, here, Coccinella was recovered as the sister group to the clade Coleomegilla and Anisosticta, while in previous studies, this genus was found to be sister group to all other genera in clade F [83] or as sister to Cycloneda ([71]; Figure 3).

These differences in the phylogenetic hypotheses of ladybird beetles discussed here could be due to the influence of the heterogeneity in nucleotide composition in the molecular dataset. Song et al. [71] indicated that the mitochondrial genes of ladybird beetles have significant saturation in the third codon position of the 13 PCGs and when PCGs are combined with the RNAs (two rRNA and 22 tRNA). We observed only two differences in the backbone of the tree and a slight variation in node support in our analyses under the amino acid partitioning scheme. Removing the third codon position of the mitochondrial PCGs in our datasets did not have an effect on the topology of the tree and the support values. The different resulting topologies and/or the support values of the nodes also could be the influence of the evolutionary substitution models (homogeneous vs. non-homogeneous), the data partition strategy (PCGs: partitioned by gene vs. gene and codon position; including all codon positions or excluding the third codon position), and the molecular markers (nuclear genes/mitochondrial: PCGs, rRNAs, tRNAs/combination of them) used in the phylogenetic inferences, which change in each study compared here. Other studies have supported that nucleoid heterogeneity, specially in mitochondrial gens, data partitioning, and evolutionary model selection can significantly influence the results of phylogenetic analysis (e.g., [85-87]). A broader data exploration taking into account the influence of the mentioned factors could be interesting to infer a new phylogeny of Coccinellidae with a larger sample of taxa and molecular markers.

\section{Conclusions}

The combination of morphology and museum collection genomics has allowed us to discover a new species of ladybird beetle, Eriopis patagonia, and infer its phylogenetic relationship based on the mitochondrial genome. We stress the importance of Natural History Collections as a source of genetic information, since NGS technology and genome skimming methods are very useful for obtaining molecular information from old museum specimens. For many ladybird beetle genera, especially those 
distributed in South America, genetic information is still lacking. Considering that in certain cases, it is not easy to obtain fresh specimens due to the difficulties in doing fieldwork (e.g., obtaining collection permits, costs, difficulty of access in some geographical areas), NGS is an attractive tool for continuing the molecular systematic study of Coccinellidae using material from biological collections.

Supplementary Materials: The following are available online at http:/www.mdpi.com/2075-4450/11/11/766/s1. Table S1. The partition schemes and best substitution models proposed by Partition Finder. Table S2. Estimates of evolutionary divergence between pairwise mitochondrial sequences of Coccinelloidea species. The value is the number of base substitutions per site between nucleotide sequences estimated by the Kimura-2-parameter model, and the variation rate among sites was modeled with a gamma distribution. The analysis was based on 9122 positions that comprise the two rRNAs and PCGs with the three-codon positions for 30 taxa. The out-groups (in blue) are included to compare with the in-group (Coccinellidae). Table S3. Estimates of evolutionary divergence between pairwise mitochondrial sequences of Coccinelloidea species. The value is the number of base substitutions per site between nucleotide sequences estimated by the Kimura-2-parameter model, and the variation rate among sites was modeled with a gamma distribution. The analysis was based on 9452 positions that comprise the PCGs with the three-codon positions for 30 taxa. The out-groups (in blue) are included to compare with the in-group (Coccinellidae). Figure S1. Maps of Eriopis patagonia Salazar and Eriopis connexa (Germar) mitogenomes. PCGs are shown in green, tRNAs are shown in blue, rRNAs genes are shown in red, and the A+T rich region is shown in orange. The direction of transcription is indicated by an arrow. The tRNAs are labeled according to the IUPAC-IUB single letter amino acid code. The dotted lines in E. patagonia mitogenome indicate that the intergenic spacer and tRNA-I were not recovered in this study. Figure S2. Eriopis connexa mitogenome. (A). Predicted secondary structure of transfer RNAs (tRNAs). The tRNAs are labeled according to the IUPAC-IUB amino acid code. Orange circles represent changes in the sequence with respect to tRNAs of the E. patagonia mitogenome. Bars indicate Watson-Crick base pairings. (B). Nucleotide composition. Protein-coding genes (PCGs), tRNAs, and ribosomal RNAs (rRNAs). Figure S3. Phylogenetic relationships of Coccinellidae. Tree inferred by the Bayesian Inference (BI) method based on 13 protein-coding genes including all codon positions and two ribosomal RNAs (PCG_RNA) from mitochondrial genomes of 28 Coccinellidae and two out-groups. Bayesian posterior probability values are indicated at the right of each node. Figure S4. Phylogenetic relationships of Coccinellidae. Tree inferred by the maximum likelihood estimation method (ML) based on 13 protein-coding genes excluding the third-codon positions and two ribosomal RNAs (PCG12_RNA) from mitochondrial genomes of 28 Coccinellidae and two out-groups. ML bootstrap support values and posterior probability values are indicated at the right of each node. Transfer bootstrap expectation value (blue) is only shown when it differs from the bootstrap value. Figure S5. Phylogenetic relationships of Coccinellidae. Tree inferred by the maximum likelihood estimation method (ML) based on 13 protein-coding genes being translated into amino acids (PCG_AA) from mitochondrial genomes of 28 Coccinellidae and two outgroups. ML bootstrap support values and posterior probability values are indicated at the right of each node. The abbreviation "- - " indicates that the node is not recovered by the BI analysis.

Author Contributions: Morphological observations, K.S.; photographic documentation and carried out the sample preparation, K.S.; analysis of molecular data, K.S., R.N.; writing-original draft, K.S.; writing-review and editing K.S., R.N.; supervision R.N.; funding acquisition R.N. All authors have read and agreed to the published version of the manuscript.

Funding: This work was supported by “ATM blanche" of the MNHN. KS's doctoral studies received financial support from the government agency COLCIENCIAS, Colombia (program number 756-2016).

Acknowledgments: We thank the team of the 'Service de Systématique Moléculaire, SSM' (UMS 2700 CNRS-MNHN) where we carried out the molecular work. We are grateful to Pascaline Chifflet-Belle (EPHE, MNHN) for the technical support with the genetic bank preparation, Delphine Gey and Céline Bonillo (MNHN) for the help with the molecular data protocols, Guillaume Achaz (MNHN) and Tony Robillard (MNHN) for their advice on improving the manuscript, Liliana Ballesteros (Université Paris-Saclay) and Ben Warren (MNHN) for improvements to the English. We are grateful to Hélène Citerne, who critically read the manuscript and revised our English. Thanks to the digitization service (MNHN-Entomology) for the access to the photography equipment. We also thank the anonymous reviewers whose comments helped to improve the manuscript.

Conflicts of Interest: The authors declare that they have no conflict of interests.

Data Availability Statement: The sequenced mitogenome is available in GenBank under accession number MN509443. The nucleotide multiple sequence alignment used for the phylogenetic analyses are available in Mendely Dataset (Mendeley Data, V1, doi:10.17632/fn8gh9kcpc.1).

New Species Registration: The following information notes the registration of the new species: Publication LSID: urn:lsid:zoobank.org:pub:4429ABB0-9247-4C6B-B625-0B66619AA06F//Eriopis patagonia Salazar sp. nov. LSID: urn:lsid:zoobank.org:act:AADAA2C8-01CF-4EB6-A0DA-20EA885D88F7. 


\section{References}

1. Meredith, L.A. Roles of natural history collections. Ann. Missouri Bot. Gard. 1996, 83, 536-545. [CrossRef]

2. Shaffer, H.; Fisher, R.; Davidson, C. The role of natural history collections in documenting species declines. Trends Ecol. Evol. 1998, 13, 27-30. [CrossRef]

3. Nattier, R. Biodiversity in natural history collections, a source of data for the study of evolution. In Biodiversity and Evolution; Grandcolas, P., Maurel, M.-C., Eds.; ISTE Press: London, UK; Elsevier: London, UK, 2018; pp. 175-187.

4. Wandeler, P.; Hoeck, P.E.A.; Keller, L.F. Back to the future: Museum specimens in population genetics. Trends Ecol. Evol. 2007, 22, 634-642. [CrossRef] [PubMed]

5. Yeates, D.K.; Zwick, A.; Mikheyev, A.S. Museums are biobanks: Unlocking the genetic potential of the three billion specimens in the world's biological collections. Curr. Opin. Insect Sci. 2016, 18, 83-88. [CrossRef] [PubMed]

6. Shendure, J.; Ji, H. Next-generation DNA sequencing. Nat. Biotechnol. 2008, 26, 1135-1145. [CrossRef]

7. Staats, M.; Erkens, R.H.J.; van de Vossenberg, B.; Wieringa, J.J.; Kraaijeveld, K.; Stielow, B.; Geml, J.; Richardson, J.E.; Bakker, F.T. Genomic treasure troves: Complete genome sequencing of herbarium and insect museum specimens. PLoS ONE 2013, 8, e69189. [CrossRef]

8. Burrell, A.S.; Disotell, T.R.; Bergey, C.M. The use of museum specimens with high-throughput DNA sequencers. J. Hum. Evol. 2015, 79, 35-44. [CrossRef] [PubMed]

9. Straub, S.C.; Parks, M.; Weitemier, K.; Fishbein, M.; Cronn, R.C.; Liston, A. Navigating the tip of the genomic iceberg: Next-generation sequencing for plant systematics. Am. J. Bot. 2012, 99, 349-364. [CrossRef] [PubMed]

10. Dodsworth, S. Genome skimming for next-generation biodiversity analysis. Trends Plant Sci. 2015, 20, 525-527. [CrossRef] [PubMed]

11. Malé, G.P.-J.; Bardon, L.; Besnard, G.; Coissac, E.; Delsuc, F.; Engel, J.; Lhuillier, E.; Scotti-Saintagne, C.; Tinaut, A.; Chave, J. Genome skimming by shotgun sequencing helps resolve the phylogeny of a pantropical tree family. Mol. Ecol. Resour. 2014, 14, 966-975. [CrossRef]

12. Berger, B.A.; Han, J.; Sessa, E.B.; Gardner, A.G.; Shepherd, K.A.; Ricigliano, V.A.; Jabaily, R.S.; Howarth, D.G. The unexpected depths of Genome-Skimming data: A case study examining Goodeniaceae floral symmetry genes. Appl. Plant Sci. 2017, 5, 1700042. [CrossRef]

13. Gryta, H.; Van de Paer, C.; Manzi, S.; Holota, H.; Roy, M.; Besnard, G. Genome skimming and plastid microsatellite profiling of alder trees (Alnus spp., Betulaceae): Phylogenetic and phylogeographical prospects. Tree Genet. Genomes 2017, 13, 118. [CrossRef]

14. Gillett, C.P.D.T.; Crampton-Platt, A.; Timmermans, M.J.T.N.; Jordal, B.H.; Emerson, B.C.; Vogler, A.P. Bulk de novo mitogenome assembly from pooled total DNA elucidates the phylogeny of weevils (Coleoptera: Curculionoidea). Mol. Biol. Evol. 2014, 31, 2223-2237. [CrossRef]

15. Crampton-Platt, A.; Timmermans, M.J.T.N.; Gimmel, M.L.; Kutty, S.N.; Cockerill, T.D.; Khen, C.V.; Vogler, A.P. Soup to tree: The phylogeny of beetles inferred by mitochondrial metagenomics of a Bornean rainforest sample. Mol. Biol. Evol. 2015, 32, 2302-2316. [CrossRef]

16. Richter, S.; Schwarz, F.; Hering, L.; Böggemann, M.; Bleidorn, C. The utility of genome skimming for phylogenomic analyses as demonstrated for glycerid relationships (Annelida, Glyceridae). Genome Biol. Evol. 2015, 7, 3443-3462. [CrossRef] [PubMed]

17. Grandjean, F.; Tan, M.H.; Gan, H.M.; Lee, Y.P.; Kawai, T.; Distefano, R.J.; Blaha, M.; Roles, A.J.; Austin, C.M. Rapid recovery of nuclear and mitochondrial genes by genome skimming from Northern Hemisphere freshwater crayfish. Zool. Scr. 2017, 46, 718-728. [CrossRef]

18. Gilbert, M.T.P.; Moore, W.; Melchior, L.; Worebey, M. DNA extraction from dry museum beetles without conferring external morphological damage. PLoS ONE 2007, 2, e272. [CrossRef] [PubMed]

19. Thomsen, P.F.; Elias, S.; Gilbert, M.T.P.; Haile, J.; Munch, K.; Kuzmina, S.; Froese, D.G.; Sher, A.; Holdaway, R.N.; Willerslev, E. Non-destructive sampling of ancient insect DNA. PLoS ONE 2009, 4, e5048. [CrossRef]

20. Hofreiter, M. Nondestructive DNA extraction from museum specimens. In Ancient DNA. Methods in Molecular Biology (Methods and Protocols); Shapiro, B., Hofreiter, M., Eds.; Humana Press: Totowa, NY, USA, 2012; pp. 93-100. ISBN 0016-6758 (Print). 
21. Tin, M.M.-Y.; Economo, E.P.; Mikheyev, A.S. Sequencing degraded DNA from non-destructively sampled museum specimens for RAD-tagging and low-coverage shotgun phylogenetics. PLoS ONE 2014, 9, e96793. [CrossRef]

22. St Laurent, R.A.; Hamilton, C.A.; Kawahara, A.Y. Museum specimens provide phylogenomic data to resolve relationships of sack-bearer moths (Lepidoptera, Mimallonoidea, Mimallonidae). Syst. Entomol. 2018, 43, 729-761. [CrossRef]

23. Wood, H.M.; González, V.L.; Lloyd, M.; Coddington, J.; Scharff, N. Next-generation museum genomics: Phylogenetic relationships among palpimanoid spiders using sequence capture techniques (Araneae: Palpimanoidea). Mol. Phylogenet. Evol. 2018, 127, 907-918. [CrossRef]

24. Timmermans, M.J.T.N.; Daghmoumi, S.M.; Glass, D.; Hamilton, C.A.; Kawahara, A.Y.; Kitching, I.J. Phylogeny of the Hawkmoth Tribe Ambulycini (Lepidoptera: Sphingidae): Mitogenomes from museum specimens resolve major relationships. Insect Syst. Divers. 2019, 3, 1-8. [CrossRef]

25. Chomicki, G.; Renner, S.S. Watermelon origin solved with molecular phylogenetics including Linnaean material: Another example of museomics. New Phytol. 2015, 205, 526-532. [CrossRef]

26. Price, B.W.; Henry, C.S.; Hall, A.C.; Mochizuki, A.; Duelli, P.; Brooks, S.J. Singing from the grave: DNA from a 180 year old type specimen confirms the identity of Chrysoperla carnea (Stephens). PLoS ONE 2015, 10, e0121127. [CrossRef]

27. Jin, M.; Zwick, A.; Ślipiński, A.; de Keyzer, R.; Pang, H. Museomics reveals extensive cryptic diversity of Australian prionine longhorn beetles with implications for their classification and conservation. Syst. Entomol. 2020, 1-26. [CrossRef]

28. Baldwin, B.G.; Jeziorski, C.; Besnard, G.; Hong-Wa, C.; Zedane, L.; Murienne, J. Museomics illuminate the history of an extinct, paleoendemic plant lineage (Hesperelaea, Oleaceae) known from an 1875 collection from Guadalupe Island, Mexico. Biol. J. Linn. Soc. 2015, 117, 44-57. [CrossRef]

29. Van de Paer, C.; Hong-Wa, C.; Jeziorski, C.; Besnard, G. Mitogenomics of Hesperelaea, an extinct genus of Oleaceae. Gene 2016, 594, 197-202. [CrossRef]

30. Bebber, D.P.; Carine, M.A.; Wood, J.R.I.; Wortley, A.H.; Harris, D.J.; Prance, G.T.; Davidse, G.; Paige, J.; Pennington, T.D.; Robson, N.K.B.; et al. Herbaria are a major frontier for species discovery. Proc. Natl. Acad. Sci. USA. 2010, 107, 22169-22171. [CrossRef]

31. Maddison, D.R.; Cooper, K.W. Species delimitation in the ground beetle subgenus Liocosmius (Coleoptera: Carabidae: Bembidion), including standard and next-generation sequencing of museum specimens. Zool. J. Linn. Soc. 2014, 172, 741-770. [CrossRef]

32. Heintzman, P.D.; Elias, S.A.; Moore, K.; Paszkiewicz, K.; Barnes, I. Characterizing DNA preservation in degraded specimens of Amara alpina (Carabidae: Coleoptera). Mol. Ecol. Resour. 2014, 14, 606-615. [CrossRef] [PubMed]

33. Kanda, K.; Pflug, J.M.; Sproul, J.S.; Desenko, M.A.; Maddison, D.R.; Dasenko, M.A.; Maddison, D.R. Successful recovery of nuclear protein- coding genes from small insects in museums using Illumina sequencing. PLoS ONE 2015, 10, e0143929. [CrossRef]

34. Sproul, J.S.; Maddison, D.R. Sequencing historical specimens: Successful preparation of small specimens with low amounts of degraded DNA. Mol. Ecol. Resour. 2017, 17, 1183-1201. [CrossRef]

35. González, G.F. Aporte al conocimiento de la tribu Coccinellini (Coleoptera: Coccinellidae) en América del Sur. Rev. Chil. Entomol. 2018, 44, 169-206.

36. González, G.F. Especies nuevas del género Eriopis Mulsant (Coleoptera: Coccinellidae) del Norte de Chile. Boletín Soc. Entomológica Aragon. 2014, 54, 61-72.

37. Ślipiński, A. Australian Ladybird Beetles (Coleoptera: Coccinellidae): Their Biology and Classification; ABRS: Canberra, Australia; CSIRO Publishing: Melbourne, Australia, 2007; ISBN 9780643109919(epdf).

38. Schindelin, J.; Arganda-Carreras, I.; Frise, E.; Kaynig, V.; Longair, M.; Pietzsch, T.; Preibisch, S.; Rueden, C.; Saalfeld, S.; Schmid, B.; et al. Fiji: An open-source platform for biological-image analysis. Nat. Methods 2012, 9, 676-682. [CrossRef] [PubMed]

39. ICZN (International Commission on Zoological Nomenclature). International Code of Zoological Nomenclature; Adopted by the International Union of Biological Sciences, 4th ed.; International Trust for Zoological Nomenclature: London, UK, 1999; ISBN 9780853010067.

40. Meyer, M.; Kircher, M. Illumina sequencing library preparation for highly multiplexed target capture and sequencing. Cold Spring Harb. Protoc. 2010, 5. [CrossRef] 
41. Andrews, S. FastQC: A Quality Control Tool for High Throughput Sequence Data. Available online: http://www.bioinformatics.babraham.ac.uk/projects/fastqc/2010 (accessed on 20 May 2019).

42. Kim, M.J.; Wan, X.; Kim, I. Complete mitochondrial genome of the seven-spotted lady beetle, Coccinella septempunctata (Coleoptera: Coccinellidae). Mitochondrial DNA 2012, 23, 179-181. [CrossRef]

43. Bernt, M.; Donath, A.; Jühling, F.; Externbrink, F.; Florentz, C.; Fritzsch, G.; Pütz, J.; Middendorf, M.; Stadler, P.F. MITOS: Improved de novo metazoan mitochondrial genome annotation. Mol. Phylogenet. Evol. 2013, 69, 313-319. [CrossRef]

44. Lowe, T.M.; Eddy, S.R. tRNAscan-SE: A program for improved detection of transfer RNA genes in genomic sequence. Nucleic Acids Res. 1997, 25, 955-964. [CrossRef]

45. Perna, N.T.; Kocher, T.D. Patterns of nucleotide composition at fourfold degenerate sites of animal mitochondrial genomes. J. Mol. Evol. 1995, 41, 353-358. [CrossRef]

46. Katoh, K.; Standley, D.M. MAFFT multiple sequence alignment software version 7: Improvements in performance and usability. Mol. Biol. Evol. 2013, 30, 772-780. [CrossRef]

47. Katoh, K.; Rozewicki, J.; Yamada, K.D. MAFFT online service: Multiple sequence alignment, interactive sequence choice and visualization. Brief. Bioinform. 2019, 20, 1160-1166. [CrossRef]

48. Capella-Gutiérrez, S.; Silla-Martínez, J.M.; Gabaldón, T. trimAl: A tool for automated alignment trimming in large-scale phylogenetic analyses. Bioinformatics 2009, 25, 1972-1973. [CrossRef]

49. Larsson, A. AliView: A fast and lightweight alignment viewer and editor for large datasets. Bioinformatics 2014, 30, 3276-3278. [CrossRef]

50. Vaidya, G.; Lohman, D.J.; Meier, R. SequenceMatrix: Concatenation software for the fast assembly of multi-gene datasets with character set and codon information. Cladistics 2011, 27, 171-180. [CrossRef]

51. Lanfear, R.; Frandsen, P.B.; Wright, A.M.; Senfeld, T.; Calcott, B. PartitionFinder 2: New methods for selecting partitioned models of evolution for molecular and morphological phylogenetic analyses. Mol. Biol. Evol. 2017, 34, 772-773. [CrossRef] [PubMed]

52. Lanfear, R.; Calcott, B.; Ho, S.Y.W.; Guindon, S. PartitionFinder: Combined selection of partitioning schemes and substitution models for phylogenetic analyses. Mol. Biol. Evol. 2012, 29, 1695-1701. [CrossRef]

53. Stamatakis, A. RAxML version 8: A tool for phylogenetic analysis and post-analysis of large phylogenies. Bioinformatics 2014, 30, 1312-1313. [CrossRef]

54. Ronquist, F.; Teslenko, M.; Van Der Mark, P.; Ayres, D.L.; Darling, A.; Höhna, S.; Larget, B.; Liu, L.; Suchard, M.A.; Huelsenbeck, J.P. Mrbayes 3.2: Efficient bayesian phylogenetic inference and model choice across a large model space. Syst. Biol. 2012, 61, 539-542. [CrossRef]

55. Miller, M.A.; Schwartz, T.; Pickett, B.E.; He, S.; Klem, E.B.; Scheuermann, R.H.; Passarotti, M.; Kaufman, S.; Oleary, M.A. A RESTful API for access to phylogenetic tools via the CIPRES science gateway. Evol. Bioinforma. 2015, 11, 43-48. [CrossRef]

56. Lemoine, F.; Wilkinson, E.; Correia, D.; Oliveira, D.; Gascuel, O.; Evolutive, B.; Town, C.; Africa, S.; Sciences, M.; Africa, S.; et al. Renewing Felsenstein's phylogenetic bootstrap in the era of big data. Nature 2018, 556, 452-456. [CrossRef]

57. Rambaut, A.; Drummond, A.J.; Xie, D.; Baele, G.; Suchard, M.A. Posterior summarization in Bayesian phylogenetics using Tracer 1.7. Syst. Biol. 2018, 67, 901-904. [CrossRef]

58. Letunic, I.; Bork, P. Interactive tree of life (iTOL) v4: Recent updates and new developments. Nucleic Acids Res. 2019, 47, w256-w259. [CrossRef]

59. Kumar, S.; Stecher, G.; Li, M.; Knyaz, C.; Tamura, K. MEGA X: Molecular evolutionary genetics analysis across computing platforms. Mol. Biol. Evol. 2018, 35, 1547-1549. [CrossRef] [PubMed]

60. Stecher, G.; Tamura, K.; Kumar, S. Molecular evolutionary genetics analysis (MEGA) for macOS. Mol. Biol. Evol. 2020, 37, 1237-1239. [CrossRef]

61. Zhang, Z.; Wang, X.; Li, R.; Guo, R.; Zhang, W.; Song, W.; Hao, C.; Wang, H.; Li, M. The mitochondrial genome of Dastarcus helophoroides (Coleoptera: Bothrideridae) and related phylogenetic analyses. Gene 2015, 560, 15-24. [CrossRef]

62. Seo, B.Y.; Park, J.; Kwon, W.; Park, J. The complete mitochondrial genome of Aiolocaria hexaspilota (Hope, 1831) (Coleoptera: Coccinellidae). Mitochondrial DNA Part B Resour. 2019, 4, 1472-1474. [CrossRef]

63. Linard, B.; Crampton-Platt, A.; Gillett, C.P.D.T.; Timmermans, M.J.T.N.; Vogler, A.P. Metagenome skimming of insect specimen pools: Potential for comparative genomics. Genome Biol. Evol. 2015, 7, 1474-1489. [CrossRef] 
64. Tang, M.; Tan, M.; Meng, G.; Yang, S.; Su, X.; Liu, S.; Song, W.; Li, Y.; Wu, Q.; Zhang, A.; et al. Multiplex sequencing of pooled mitochondrial genomes-a crucial step toward biodiversity analysis using mito-metagenomics. Nucleic Acids Res. 2014, 42, e166. [CrossRef]

65. Yuan, M.-L.; Zhang, L.-J.; Zhang, Q.-L.; Zhang, L.; Li, M.; Wang, X.-T.; Feng, R.-Q.; Tang, P.-A. Mitogenome evolution in ladybirds: Potential association with dietary adaptation. Ecol. Evol. 2020, 10, 1042-1053. [CrossRef]

66. Timbó, R.V.; Togawa, R.C.; Costa, M.M.C.; Andow, D.A.; Paula, D.P. Mitogenome sequence accuracy using different elucidation methods. PLoS ONE 2017, 12, e0179971. [CrossRef]

67. Niu, F.-F.; Zhu, L.; Wang, S.; Wei, S.-J. The mitochondrial genome of the multicolored Asian lady beetle Harmonia axyridis (Pallas) and a phylogenetic analysis of the Polyphaga (Insecta: Coleoptera). Mitochondrial DNA 2016, 27, 2725-2727. [CrossRef] [PubMed]

68. Hao, Y.-N.; Liu, C.-Z.; Sun, Y.-X. The complete mitochondrial genome of the Adonis ladybird, Hippodamia variegata (Coleoptera: Coccinellidae). Mitochondrial DNA Part B Resour. 2019, 4, 1087-1088. [CrossRef]

69. Zhou, J.; Li, R.; Kong, Y.; Hu, H.-W.; Shu, X.-H. Mitochondrial genome of Lemnia saucia Mulsant (Coleoptera: Coccinellidae) and phylogenetic analysis. Mitochondrial DNA Part B 2019, 4, 1441-1442. [CrossRef]

70. Behere, G.T.; Firake, D.M.; Tay, W.T.; Azad Thakur, N.S.; Ngachan, S.V. Complete mitochondrial genome sequence of a phytophagous ladybird beetle, Henosepilachna pusillanima (Mulsant) (Coleoptera: Coccinellidae). Mitochondrial DNA 2016, 27, 291-292. [CrossRef]

71. Song, N.; Li, X.; Yin, X.; Li, X.; Xi, Y. The mitochondrial genomes of ladybird beetles and implications for evolution and phylogeny. Int. J. Biol. Macromol. 2020, 147, 1193-1203. [CrossRef]

72. Li, H.S.; Liang, X.Y.; Zou, S.J.; Liu, Y.; De Clercq, P.; Ślipiński, A.; Pang, H. Episodic positive selection at mitochondrial genome in an introduced biological control agent. Mitochondrion 2016, 28, 67-72. [CrossRef]

73. Nattier, R.; Salazar, K. Next-generation sequencing yields mitochondrial genome of Coccidophilus cariba Gordon (Coleoptera: Coccinellidae) from museum specimen. Mitochondrial DNA Part B 2019, 4, 3780-3781. [CrossRef]

74. Cambefort, Y. Des Coléoptères, des Collections et des Hommes; Publications Scientifiques du Muséum national d'Histoire naturelle; Collection Archives: Paris, France, 2006.

75. Fairmaire, L. Coléoptères. In Recherches sur les Insectes Recueillis Pendant la Mission Chargée D'observer à Santa-Cruz de Patagonie le Passage de Vénus.; Lebrun, E.D., Fairmaire, L., Mabille, P., Eds.; 3ème Série; Nouvelles Archives du Muséum D’histoire Naturelle: Paris, France, 1889; Volume 1, pp. 101-137.

76. Bustamante-Navarrete, A.A.; Oroz-Ramos, A.J. Eriopis santiagoi n. sp., nueva especie del género Eriopis Mulsant, 1850 (Coleoptera: Coccinellidae), de Junín, Perú. Entomotropica 2016, 31, 186-195.

77. Venn, S. To fly or not to fly: Factors influencing the flight capacity of carabid beetles (Coleoptera: Carabidae). Eur. J. Entomol. 2016, 113, 587-600. [CrossRef]

78. Boucher, S. Évolution et phylogénie des Coléoptères Passalidae (Scarabaeoidea). Les taxons du groupe famille. La tribu néotropicale des Proculini et son complexe Veturius. Ann. Soc. Entomol. Fr. (N. S.) 2006, 41, 239-604. [CrossRef]

79. Mulsant, M.E.; Deuxième, S. Species des Coléoptères Trimères Sécuripalpes; Annales des Sciences Physiques et Naturalles d'Agriculture et D'industrie: Lyon, Paris, 1850.

80. Brèthes, J. Sur une collection de coccinellides (et un Phalacridae) du British Muséum. An. Mus. Nac. Hist. Nat. Bernardino Rivadavia 1924, 33, 144-176.

81. Jühling, F.; Pütz, J.; Bernt, M.; Donath, A.; Middendorf, M.; Florentz, C.; Stadler, P.F. Improved systematic tRNA gene annotation allows new insights into the evolution of mitochondrial tRNA structures and into the mechanisms of mitochondrial genome rearrangements. Nucleic Acids Res. 2012, 40, 2833-2845. [CrossRef] [PubMed]

82. Wolstenholme, D.R. Animal mitochondrial DNA: Structure and evolution. Int. Rev. Cytol. 1992, 141, $173-216$. [CrossRef]

83. Escalona, H.E.; Zwick, A.; Li, H.S.; Li, J.; Wang, X.; Pang, H.; Hartley, D.; Jermiin, L.S.; Nedvěd, O.; Misof, B.; et al. Molecular phylogeny reveals food plasticity in the evolution of true ladybird beetles (Coleoptera: Coccinellidae: Coccinellini). BMC Evol. Biol. 2017, 17, 151. [CrossRef] 
84. Vandenberg, N.J.; Gonzalez, G. Review of lady beetles in the Cycloneda germainii species complex (Coleoptera; Coccinellidae: Coccinellinae: Coccinellini) with descriptions of new and unusual species from Chile and surrounding countries. Zootaxa 2006, 1311, 13-50.

85. Cai, C.; Tihelka, E.; Pisani, D.; Donoghue, P.C.J. Data curation and modeling of compositional heterogeneity in insect phylogenomics: A case study of the phylogeny of Dytiscoidea (Coleoptera: Adephaga). Mol. Phylogenet. Evol. 2020, 147, 106782. [CrossRef]

86. Timmermans, M.J.T.N.; Barton, C.; Haran, J.; Ahrens, D.; Culverwell, C.L.; Ollikainen, A.; Dodsworth, S.; Foster, P.G.; Bocak, L.; Vogler, A.P. Family-level sampling of mitochondrial genomes in Coleoptera: Compositional heterogeneity and phylogenetics. Genome Biol. Evol. 2016, 8, 161-175. [CrossRef]

87. Liu, Y.; Song, F.; Jiang, P.; Wilson, J.J.; Cai, W.; Li, H. Compositional heterogeneity in true bug mitochondrial phylogenomics. Mol. Phylogenet. Evol. 2018, 118, 135-144. [CrossRef]

Publisher's Note: MDPI stays neutral with regard to jurisdictional claims in published maps and institutional affiliations.

(C) 2020 by the authors. Licensee MDPI, Basel, Switzerland. This article is an open access article distributed under the terms and conditions of the Creative Commons Attribution (CC BY) license (http://creativecommons.org/licenses/by/4.0/). 